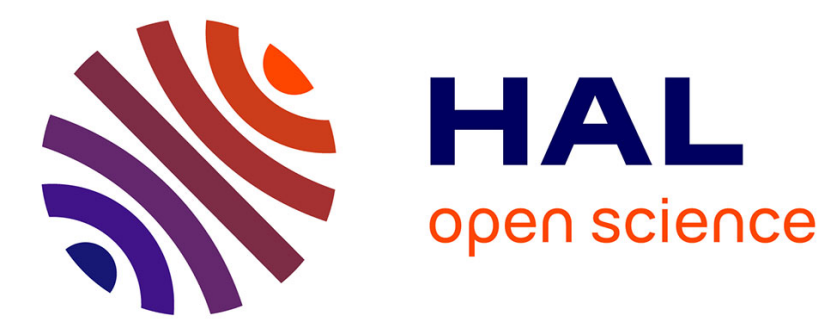

\title{
Exploring the role of water chemistry on metal accumulation in biofilms from streams in mining areas
}

Vincent Laderriere, Séverine Le Faucheur, Claude Fortin

\section{To cite this version:}

Vincent Laderriere, Séverine Le Faucheur, Claude Fortin. Exploring the role of water chemistry on metal accumulation in biofilms from streams in mining areas. Science of the Total Environment, 2021, 784, pp.146986. 10.1016/j.scitotenv.2021.146986 . hal-03214882

\section{HAL Id: hal-03214882 \\ https://hal.science/hal-03214882}

Submitted on 13 Jan 2022

HAL is a multi-disciplinary open access archive for the deposit and dissemination of scientific research documents, whether they are published or not. The documents may come from teaching and research institutions in France or abroad, or from public or private research centers.
L'archive ouverte pluridisciplinaire HAL, est destinée au dépôt et à la diffusion de documents scientifiques de niveau recherche, publiés ou non, émanant des établissements d'enseignement et de recherche français ou étrangers, des laboratoires publics ou privés. 


\title{
Exploring the role of water chemistry on metal accumulation
}

\section{in biofilms from streams in mining areas}

\author{
Vincent Laderriere ${ }^{1}$, Séverine Le Faucheur ${ }^{2}$, Claude Fortin ${ }^{1}$
}

${ }^{1}$ Institut national de la recherche scientifique, Centre Eau Terre Environnement, 490 rue de la Couronne, Québec, Canada

${ }^{2}$ Université de Pau et des Pays de l'Adour, e2s-UPPA, IPREM, 2 avenue Pierre Angot, Pau, France

Corresponding author : claude.fortin@ete.inrs.ca
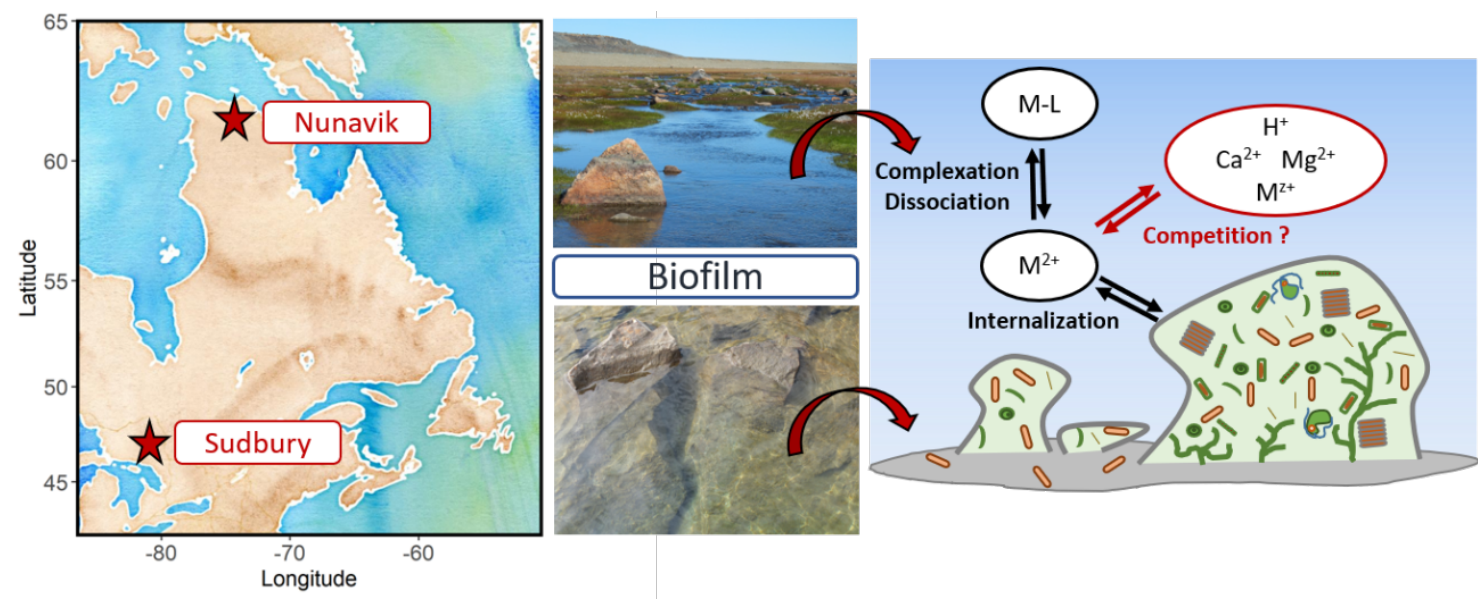


\section{ABSTRACT}

Biofilms play a key role in aquatic ecosystems. They are ubiquitous, even in the most contaminated ecosystems, and have great potential as biomonitors of exposure to contaminants such as metals. Freshwater biofilms and surface waters were sampled in two active mining areas of Canada: in the northern part of Nunavik (Quebec) and in the Greater Sudbury area (Ontario). Significant linear relationships were found between both total dissolved and free metal ion concentrations with biofilm metal contents for $\mathrm{Cu}$ and $\mathrm{Ni}$, but not for $\mathrm{Cd}$. When $\mathrm{pH}$ was below 6 , biofilms accumulated less metals than at higher pHs. These results confirm that protons have a protective effect, leading to lower internalized metal concentrations. When considering only the sites where $\mathrm{pH}$ was above 6 , the linear relationships between metal concentrations in water and in biofilms were improved for all three studied metals. The presence of metal ions could also modify the internalization of a given metal. To further study the role of cations as competitors to $\mathrm{Cu}, \mathrm{Ni}$ and $\mathrm{Cd}$ uptake, relationships between the ratio of biofilm metal contents $(\mathrm{Cu}, \mathrm{Ni}$ and $\mathrm{Cd})$ on the ambient free metal ion concentrations were built as a function of potential cation competitors, such as major cations and metals. Surprisingly, our data suggest that calcium plays a minor role in preventing metal accumulation as compared to magnesium and possibly other metals. At a global scale, metal accumulation remained highly consistent between the two studied regions and over the sampling period, despite differences in ambient physicochemical water characteristics, climate or types of ecosystems. Metal bioaccumulation is thus a promising biomarker to assess metal bioavailability in a mining context. Nevertheless, more data are still required to further highlight the contribution of each competitor in metal accumulation by biofilms and to be able to build a unifying predictive model.

Keywords: Biotic ligand model, Metal speciation, Biomonitoring, Nickel, Copper, Cadmium 


\section{INTRODUCTION}

Human activities, such as mining operations, release significant amounts of metals into aquatic environments, which may exert pressures on aquatic ecosystems (Tercier-Waeber et al., 2012). Measuring the total dissolved concentration can identify the level of exposure to living organisms but it does not provide information on the bioavailability of metals. Total metal concentrations are thus not always representative of ecotoxicological risk. Indeed, metals are present under several chemical forms in natural waters, which influence their bioavailability (Erickson, 2013; Adams et al., 2020). Sites with similar total metal concentrations may result in different rates of bioaccumulation in aquatic organisms. For instance, Lopez et al. (2017) demonstrated that the accumulation of arsenic in benthic invertebrates varied significantly with $\mathrm{pH}$ for exposures to similar concentrations.

While high concentrations of metals can have direct toxic effects, mining activities often result in additional changes to water quality (Cadmus et al., 2016). For instance, these operations can generate acid mine drainage, which can cause acidification when introduced to aquatic systems. This acidic byproduct is often neutralized by the addition of $\mathrm{CaO}$, however, this subsequently yields high concentrations of cations that influence hardness (i.e. Ca) within receiving waters (Kalin et al., 2006). Similar to the $\mathrm{pH}$ of water, changes in water hardness have been shown to modify metal bioavailability. As explained by Tercier-Waeber et al. (2012) competition of $\mathrm{H}^{+}, \mathrm{Mg}^{2+}$ and $\mathrm{Ca}^{2+}$ occurs at the transport binding sites of a metal. Additionally, competition between $\mathrm{H}^{+}$and metals for binding ligands in ambient water can change metal speciation and thus bioavailability. In recent decades, models have been developed to describe the interaction of metals with biological membranes, such as the Free Ion Activity Model (FIAM) and later on, the Biotic Ligand Model (BLM; Morel, 1983; Campbell \& Fortin, 2013). These two models predict that the biological response to metal exposure is mainly proportional to its free ion concentration, with the BLM incorporating the competitive effects of ions at the membrane surface. Applying such models to 
field data can be challenging, however, as metal interactions to exposed organisms differ with the physicochemical composition of the medium and biotic factors specific to each organism.

The biomonitoring approach has proven to be very useful as a proxy for the bioavailability of metals in the field. In recent years, many biological models have been used in natural waters, such as fish (Weber et al., 2008; Martyniuk et al., 2020), invertebrates (Lebrun et al., 2015; Mebane et al., 2020) or freshwater periphytic biofilms (Xie et al., 2010; Faburé et al., 2015). The latter are particularly useful for a biomonitoring approach in natural waters; they are sedentary, ubiquitous and at the base of the trophic chain. Biofilms (or periphyton) are a community constituted of a variety of autotrophic and heterotrophic microorganisms (such as bacteria, microalgae, fungi and micromeiofauna) included in a self-produced matrix of extracellular polymeric substances (EPS; Flemming \& Wingender, 2010; Battin et al., 2016). Because biofilms are an assemblage of many organisms, some studies use one group inside the biofilm, such as diatom communities, as a bioindicator of contaminants by their presence or absence (Morin et al., 2012; Morin et al., 2016; Tolotti et al., 2019). Biological interactions (e.g. mobility, predation or food selection behavior) within the biofilm community can also be modified by contaminants, and thus can be used as a marker of direct or indirect effect (Neury-Ormanni et al., 2020). Numerous studies successfully used biofilms as biomonitors because they are known to respond quickly to organic or metal contaminants (Chaumet et al., 2019; Bradac et al., 2010; Lavoie et al., 2012a). Furthermore, some studies have demonstrated that diet is a predominant exposure route and that metals can be transferred from biofilm to grazers (Xie et al., 2010; Kim et al., 2012). Freshwater biofilms seem therefore suitable for long-term monitoring and allow for metal toxicity to be assessed at a community level.

Statistically significant relationships between free metal ion concentrations in surface waters and intracellular metal concentrations in biofilms (for $\mathrm{Cd}, \mathrm{Cu} \mathrm{Ni}, \mathrm{Pb}$ and $\mathrm{Zn}$ ) were previously observed from samples collected in the vicinity of mine tailings and operations (Lavoie et al., 2012; 
Laderriere et al., 2020). This suggests that metal content in biofilms could be used as a proxy of metal exposure and could play the role of a natural "passive sampler". In addition, the authors demonstrated that accumulation of metals by biofilms was modulated by major cations and protons, in agreement with the BLM principles. It was suggested that the biofilm response is robust over time and coherent over large geographical areas (Leguay et al., 2016; Laderriere et al., 2020) for $\mathrm{Cd}, \mathrm{Cu}, \mathrm{Pb}$ and $\mathrm{Zn}$ but additional data were needed for $\mathrm{Ni}$. In the present study, we compared two different types of ecosystems (nordic and temperate areas) impacted by Ni mining. This also provided an opportunity to further test the response of this biomonitoring tool for $\mathrm{Cd}$ and $\mathrm{Cu}$. To characterize the anthropogenic pressure in these two mining areas, the biofilm metal content, as well as the dissolved metal concentrations, were measured and the free metal ion concentrations were subsequently estimated. For both regions, metal accumulation data were assessed as a function of protons, major cations or other metals to characterize potential competing effects and to identify parameters needed to be considered in the development of a predictive tool for metal bioavailability using freshwater biofilms.

\section{MATERIALS \& METHODS}

\subsection{Study area}

The present study sites were located in two different mining regions of Canada: the northern part of Nunavik in Quebec and the Greater Sudbury area in Ontario. Both regions are characterized by an intensive extraction of $\mathrm{Ni}, \mathrm{Cu}$ and precious metals. However, both areas are different in terms of geology, climate and ecosystem. The sampling was designed to capture a representative metal contamination gradient of these two regions as well as different physicochemical conditions. The detailed sampling map of both regions is presented in Figure 1. 


\subsubsection{Northern Nunavik region}

Nunavik is the largest administrative region of Quebec and is located north of the $60^{\text {th }}$ parallel. Although sparsely populated, this vast area is the home of indigenous populations and is thought to hold large metal reserves. Located on the Canadian Shield, it has a metal-rich geological composition. Two field campaigns were undertaken during the summer of 2016 (July and August) in the vicinity of the Nunavik Nickel mine (Canadian Royalties Inc.) operated by Jilien Jien Nickel Industry Co., Ltd. Currently, this mine extracts primary metals such as $\mathrm{Cu}$ and $\mathrm{Ni}$, but also lanthanides and precious metals such as $\mathrm{Au}, \mathrm{Ag}$ and $\mathrm{Co}$. It is an open-pit mine located $400 \mathrm{~km}$ north of the boreal forest northern limit and $59 \mathrm{~km}$ west of the Inuit village of Kangiqsujuaq. The mine discharges its treated effluents into the Puvirnituq River. This river is the main source of drinking water for the village of Puvirnituq, which is located $260 \mathrm{~km}$ downstream from the effluent discharge site. The treated effluents are discharged between June and September and sampling dates were chosen accordingly to capture any potential metal contamination. During the sampling campaigns, the mine had two main operating sites, the Expo site (in operation since 2012) and the Mesamax site (since 2013). In total, 18 sites were sampled in the vicinity of these two operating sites. For a more detailed description of the study sites, the reader is referred to a previous publication (Lavoie et al., 2018). Data on biofilm metal content from sampling expeditions in 2014 and 2015 have also been the focus of a previous publication (Laderriere et al., 2020).

\subsubsection{Southern Ontario region}

The second study area is located further south in the Greater Sudbury area in Ontario. This area has a long mining history and hosts a population of 160000 . Ontario is the most active mining province in Canada, and is one of the world's largest producers of $\mathrm{Ni}$ and $\mathrm{Cu}$. The first smelter was built in 1888 and six mines were in operation within a $20-\mathrm{km}$ radius of Sudbury: Garson (Valve Canada Limited), Stobie (Valve Canada Limited), Clarabelle (Valve Canada Limited), Copper Cliff North (Valve Canada Limited), Creighton (Valve Canada Limited) and Nickel Rim South (Glencore 
Canada Corporation). In September 2016, nine sites were sampled along the Junction Creek River. This is the main river flowing through the City of Sudbury, which receives the city's discharged effluent as well as effluents from nearby mines. In addition, ten sites were also sampled from tributaries of the Junction Creek River (Maley Branch Creek, Frood Branch Creek, Nolin Creek, Copper Cliff Creek), Coniston Creek and the North Veuve river. For more historical details on the region, the reader is referred to our previous study (Lavoie et al., 2018) in which the general water chemistry is presented.

\subsection{Surface water collection and analyses}

Each site was sampled for water chemistry in triplicate $(n=3)$. Unless otherwise mentioned, all plasticware to be used for cation work was previously soaked in $10 \%(\mathrm{v} / \mathrm{v}) \mathrm{HNO}_{3}(\mathrm{ACS}$ grade; Fisher Scientific) for $24 \mathrm{~h}$, thoroughly rinsed three times with distilled water and three times with ultrapure water $(18 \mathrm{M} \Omega \cdot \mathrm{cm})$, and dried under a laminar flow hood. Sampling bottles $(15 \mathrm{~mL} ; \mathrm{HDPE}$; Nalgene) were pre-acidified to $0.2 \%(\mathrm{v} / \mathrm{v}) \mathrm{HNO}_{3}$ (trace metal grade; Fisher) before sampling. Plasticware for anion and dissolved organic carbon (DOC) work was rinsed six times using ultrapure water and dried under a laminar flow hood. For total phosphorus samples, unwashed new tubes (50 mL; polypropylene (PP); Sarstedt) were used and were pre-acidified to $0.2 \%(\mathrm{v} / \mathrm{v}$ ) $\mathrm{H}_{2} \mathrm{SO}_{4}$ (Fisher Scientific) before sampling. In the field, syringes (20 mL; PP; Fisher Scientific) were used and fully rinsed three times on-site with surface water. Affixed disposable polysulfonate encapsulated filters $(0.45 \mu \mathrm{m}$ porosity; VWR International) were purged prior to use with $5 \mathrm{~mL}$ of surface water before sampling. Triplicate $15 \mathrm{~mL}$ filtered samples were obtained for the subsequent analyses of major cations and metals. This was repeated to obtain triplicate filtered samples for the analyses of major anions and DOC. Bulk unfiltered water samples were also taken for total phosphorus analysis. After sampling, all bottles were kept on ice in a cooler for transport and later stored at $4^{\circ} \mathrm{C}$. Additionally, at each site, blanks were generated using ultra-pure water which 
underwent the same manipulations as field samples for the purpose of investigating possible procedural contamination (blanks were prepared for cations, anions and DOC analyses).

\subsection{Biofilm collection and metal content}

The biofilm considered in the present study corresponds to a periphytic biofilm collected using toothbrushes by scraping several benthic rocks. A new toothbrush was used at each site and rinsed with ambient surface water before use. The collected biofilms were composite samples of four randomly selected rocks. Each sampled biofilm was collected in trace metal grade unwashed new tube (50 mL; PP; Sarstedt) and re-suspended with site water. All samples were centrifuged (5 min, 4000g) at the end of each day. The pellet was resuspended in $15 \mathrm{~mL}$ of $10 \mathrm{mM}$ ethylenediaminetetraacetic acid (EDTA) solution at $\mathrm{pH}$ 7. The chelator EDTA was used to extract adsorbed metals in order to differentiate between intra- and extracellular contents (Meylan et al., 2004; Lavoie et al., 2012b; Crémazy et al., 2013). The EDTA solution was withdrawn and the pellet was kept frozen prior to freeze-drying for $48 \mathrm{~h}$ (Dura-Top/Dura-dry MP; FTS SYSTEMS). A cold, partial digestion of $30 \mathrm{mg}$ of dry mass (precisely weighed) was performed with the addition of 0.8 $\mathrm{mL}$ of concentrated $\mathrm{HNO}_{3}$ (Trace Metal Grade; Fisher Scientific) for $48 \mathrm{~h}$. Then, $0.2 \mathrm{~mL}$ of concentrated $\mathrm{H}_{2} \mathrm{O}_{2}$ (Optima Grade; Fisher Scientific) was added and allowed to stand for another $48 \mathrm{~h}$. An aliquot of $0.8 \mathrm{~mL}$ of mineralization supernatant was collected and transferred to a new $13 \mathrm{~mL}$ tube (PP; Sarstedt) containing $7.2 \mathrm{~mL}$ of milli-Q water for a final volume of $8 \mathrm{~mL}$ resulting in a $10 \%$ of $\mathrm{HNO}_{3}$ matrix $(\mathrm{v} / \mathrm{v})$. The solutions were then stored in the refrigerator $\left(4^{\circ} \mathrm{C}\right)$ prior to analysis. Digestions were also performed on certified materials of lichen and algae from the International Atomic Energy Agency (IAEA-336, IAEA-413 and IAEA-450). Measured metal contents of certified material were all higher than $80 \%$ of certified values $(80.5 \pm 0.6 \% \mathrm{Cu}, 81 \pm$ $0.5 \% \mathrm{Ni}, 85.7 \pm 0.6 \% \mathrm{Cd} ; \mathrm{n}=3)$. 


\subsection{Analyses}

For water and biofilm samples, cations ( $\mathrm{Na}, \mathrm{Mg}, \mathrm{Al}, \mathrm{Si}, \mathrm{K}, \mathrm{Ca}, \mathrm{Mn}, \mathrm{Fe}$ ) and metals (Ni, Cu Zn, $\mathrm{Cd}, \mathrm{Pb}$ ) were measured by inductively coupled plasma-atomic emission spectrometry (ICP-AES; Varian Vista $\mathrm{AXCCD})$, and anions $\left(\mathrm{Cl}^{-}, \mathrm{F}^{-}, \mathrm{SO}_{4}{ }^{2-}\right.$ and $\left.\mathrm{NO}_{3}{ }^{-}\right)$were measured by ion chromatography (Dionex Autolon; System DX300). Trace element ( $\mathrm{Zn}, \mathrm{Cu}, \mathrm{Cd}$, and $\mathrm{Pb}$ ) concentrations in water and biofilm were also determined by ICP-mass spectrometry (Thermo instrument model X7). The DOC samples were analyzed using a total organic carbon analyzer (TOC-500A; Shimadzu) and total phosphorus concentrations were determined using persulfate digestion colorimetry (SM 4500-PB). For several sites, $\mathrm{Zn}$ measured concentrations as well as those of $\mathrm{Pb}$ were sometimes lower than field background blank samples. Because of the overall very low $\mathrm{Zn}$ and $\mathrm{Pb}$ concentrations observed at our sampling sites, we focused our data analyses on $\mathrm{Cd}$, $\mathrm{Cu}$ and $\mathrm{Ni}$.

\subsection{Metal speciation}

The Windermere Humic Acid Model VII (WHAM) was used to estimate metal speciation in natural waters (Lofts and Tipping, 2011). This software allows for calculating the concentrations of metal species at equilibrium using input parameters such as the measured concentrations of cations, anions and DOC as well as $\mathrm{pH}$. Total carbonates were assumed to be at equilibrium with the atmosphere $\left(3.09 \times 10^{-4} \mathrm{~atm}\right)$ and the default thermodynamic database was used. The concentrations of fulvic (FA) and humic (HA) acids were required for modelling purposes, which were estimated from the concentrations of dissolved organic carbon (DOC). The proportion of FA to HA was assumed to be at a 3:1 ratio and metal binding DOC to represent $60 \%$ of the dissolved organic matter, which is made of $50 \%$ C (Perdue and Ritchie, 2003). 


\subsection{Metal accumulation model}

The BLM is a conceptual model developed to explain how dissolved metals interact with biological membranes and thus, eventually enter aquatic organisms (Campbell and Fortin, 2013). The biological response to a metal is assumed to be proportional to its internalization and subsequent binding to sensitive intracellular sites. If we consider that a cell membrane receptor (noted as $\left.\left\{\equiv X^{-}\right\}\right)$could interact with a proton $\left(\mathrm{H}^{+}\right)$, a cation $\left(\mathrm{Cat}^{\mathrm{z}}\right)$, or a metal $\left(\mathrm{M}^{\mathrm{z}}\right)$ with equilibrium constants $\mathrm{K}_{\mathrm{H}}, \mathrm{K}_{\mathrm{C}}$ and $\mathrm{K}_{\mathrm{M}}$, respectively, we can write:

$$
\begin{array}{ll}
\equiv X^{-}+H^{+} \stackrel{K_{H}}{\leftrightarrow} \equiv X-H & K_{H}=\frac{\{\equiv X-H\}}{\left\{\equiv X^{-}\right\} \cdot\left[H^{+}\right]} \\
\equiv X^{-}+C a t^{Z+} \stackrel{K_{C}}{\leftrightarrow} \equiv X-C & K_{C}=\frac{\{\equiv X-C\}}{\left\{\equiv X^{-}\right\} \cdot\left[\mathrm{Cat}^{z+}\right]} \\
\equiv X^{-}+M^{z+} \stackrel{K_{M}}{\leftrightarrow} \equiv X-M & K_{M}=\frac{\{\equiv X-M\}}{\left\{\equiv X^{-}\right\} \cdot\left[M^{z+}\right]}
\end{array}
$$

We assumed that $\{\equiv X-M\}<\left\{\equiv X^{-}\right\}$because of the relatively low concentrations of trace elements in freshwaters, which allows us to consider the following as described by Leguay et al. (2016):

$$
\{\equiv X\}_{\text {Tot }}=\left\{\equiv X^{-}\right\}+\{\equiv X-H\}+\{\equiv X-\text { Cat }\}+\{\equiv X-M\}
$$

If we combine Eq 4 with Eqs 1, 2 and 3, we obtain:

$$
[\equiv X-M]=\frac{K_{M}\left[M^{Z+}\right] \times[\equiv X]_{T o t}}{1+K_{H}\left[H^{+}\right]+\sum_{i}\left(K_{C}\left[\operatorname{Cat}_{i}^{Z+}\right]\right)}
$$

Note that a proportionality constant $a$ is inserted to link metal binding to steady-state metal content in biofilms $\left(\left[M_{B i o}\right]\right)$ :

$$
\left[M_{B i o}\right]=\frac{a \times K_{M}\left[M^{Z+}\right] \times[\equiv X]_{T o t}}{1+K_{H}\left[H^{+}\right]+\sum_{i}\left(K_{C}\left[\mathrm{Cat}_{i}^{z+}\right]\right)}
$$




\subsection{Data treatment}

Unless otherwise indicated, results are given as the mean \pm one standard deviation for a minimum of three replicates. Statistical analyses and figures were performed using R software ( $v$. 4.0; https://cran.r-project.org). No outlier treatment was applied.

\section{RESULTS \& DISCUSSIONS}

\subsection{General water chemistry}

Physicochemical parameters measured for both regions are presented in Figure 2. The mean values and standard deviations of the physicochemical parameters of the surface water sampled at each site and for both regions are publicly available (https://doi.org/10.5683/SP2/RBIM04). Among the measured parameters, only $\mathrm{T}, \mathrm{Fe}, \mathrm{Mn}, \mathrm{Ni}$ and $\mathrm{Pb}$ did not show significant differences between the two studied regions.

In Nunavik, very low pH values were measured near the extraction sites. The closest sampling sites, i.e. Expo sites (EX2, EX3, EX4 and EX4C), had pH values below 5, or even 4 in the case of EX3. In Sudbury, only the CCC site situated downstream of wastewater releases from the Copper Cliff mine was slightly acidic, with a $\mathrm{pH}$ value below $6(\mathrm{pH}=5.75)$. From the 18 sampling sites in Nunavik, 12 were acidic $(\mathrm{pH}<6)$ whereas in Sudbury, only one site out of the 19 sampled had a $\mathrm{pH}$ value below 6 . Excluding these sites, the average $\mathrm{pH}$ values were around $6.5 \pm 0.4$ for the Nunavik region and $7.2 \pm 0.5$ for the Sudbury area. Moreover, the Sudbury area is characterized by average DOC values of $4.3 \pm 2.4 \mathrm{mg} / \mathrm{L}$ compared to $1.9 \pm 0.7 \mathrm{mg} / \mathrm{L}$ for Nunavik, these values being statistically different (Figure 2). This difference can be explained by the higher biological productivity in the Sudbury area compared to Nunavik. Indeed, the Sudbury area in southern Ontario is characterized by an important forest cover with a mixture of coniferous and deciduous trees. In contrast, Nunavik has a polar climate with an ecosystem corresponding to herbaceous 
tundra. The acidic $\mathrm{pHs}$ found in Nunavik may also contribute to the observed low concentrations of organic matter since the solubility of humic acids decrease with acidity (Perdue and Ritchie, 2003). Lower phosphate concentrations in Nunavik are another significant difference between the two regions. Note that the Nunavik data were consistent over time for the two sampling periods (July and August) and with the data obtained in 2014 and 2015 (Laderriere et al., 2020).

\subsection{Dissolved metal concentrations}

High concentrations of dissolved metals ( $\mathrm{Ni}, \mathrm{Cu}$ and $\mathrm{Cd}$ ) were found in mining impacted surface waters for both regions. The most contaminated sites were characterized by metal concentrations that were one to several orders of magnitude higher than the reference sites in both the Sudbury area (MBC and VR) and in Nunavik (CEx1, CEx2, C and M0). The Sudbury reference sites $\mathrm{MBC}$ and VR had concentrations below $310 \mathrm{nM}, 31 \mathrm{nM}$ and $0.3 \mathrm{nM}$ for $\mathrm{Ni}$, Cu and Cd, respectively. In the case of Nunavik, the control sites had concentrations below $250 \mathrm{nM}, 30$ $\mathrm{nM}$ and $0.6 \mathrm{nM}$ for $\mathrm{Ni}, \mathrm{Cu}$ and $\mathrm{Cd}$, respectively. Overall, higher background concentrations of dissolved metals were found in Sudbury. Although the total dissolved Ni concentrations were not statistically different between the two regions, the range of $\mathrm{Ni}$ concentrations was much greater in Nunavik $\left(10^{-8}-10^{-3} \mathrm{M}\right)$ than in Sudbury $\left(10^{-7}-10^{-5} \mathrm{M}\right)$. Similarly, Cu and Cd concentrations spanned over a larger range of values in Nunavik than in Sudbury, and showed statistical differences between the two regions (Figure 2).

The sites with the highest concentrations were sampling points located near the operating sites; the Expo sites in the case of Nunavik (EX1, EX2, EX3, EX4 and EX4C) and the Nolin Creek sites (NC1, NC2 and NC3) in the case of the Sudbury area. Indeed, the EX3 site was characterized by the highest concentrations of dissolved metals reported, with $1.2 \pm 0.4 \mathrm{mM} \mathrm{Ni}, 0.22 \pm 0.06 \mathrm{mM}$ Cu and $0.15 \pm 0.05 \mu \mathrm{M}$ Cd. The Mesamax sites (M0, M1, M2, M3, M4 and MA) and effluent sites (EF0, EF1, EF2, EF3) located further away from the mine $(\sim 6 \mathrm{~km})$ showed concentrations in the $\mu \mathrm{M}$ range. In the Sudbury area, the tributaries receiving mining effluents had the highest 
concentrations. For example, Frood Branch Creek (FBC) and Nolin Creek (NC1, NC2 and NC3) were the most contaminated with concentrations in the $\mu \mathrm{M}$ range for $\mathrm{Ni}$ and $\mathrm{Cu}$, and $\mathrm{nM}$ for $\mathrm{Cd}$. These rivers receive effluents from the Frood and Nolin mines, respectively. The highest observed concentrations were at the NC1 for Ni with concentrations of $17.7 \pm 0.05 \mu \mathrm{M}$, and at the NC2 for $\mathrm{Cu}$ and $\mathrm{Cd}$ with concentrations of $0.60 \pm 0.04 \mu \mathrm{M}$ and $4.37 \pm 0.05 \mathrm{nM}$, respectively. Frood branch and Nolin creeks are both tributaries of the Junction Creek (JC) River and flow into it between JC5 and JC6 sampling sites. Additional sampling points were selected along Junction Creek and the JC7 site had the highest dissolved Ni concentration $(4.95 \pm 0.01 \mu \mathrm{M})$ among the JC sites; the JC7 site is located just after the discharge of the Sudbury municipal wastewater treatment facilities. The concentrations found at sites $\mathrm{JC} 1$ to $\mathrm{JC} 3$ remained high $(>3 \mu \mathrm{M} \mathrm{Ni})$, which is due to the Garson mine located upstream from JC1 where effluents are discharged. As mentioned in previous studies (Lavoie et al., 2018; Lavoie et al., 2019), these two regions are strongly affected by mining activities with metal concentrations exceeding the recommended values of the Canadian Council of Ministers of the Environment in many cases (Canadian Council of Ministers of the Environment, 2014). Based on an average water hardness (142 $\mathrm{mg} \mathrm{CaCO}_{3} / \mathrm{L}$ for Nunavik and $478 \mathrm{mg} \mathrm{CaCO} / \mathrm{L}$ for Sudbury), the chronic exposure criteria were $0.055 \mu \mathrm{M} \mathrm{Cu}, 2.1 \mu \mathrm{M} \mathrm{Ni}$ and $1.9 \mathrm{nM}$ Cd for Nunavik, and $0.063 \mu \mathrm{M} \mathrm{Cu}, 2.6 \mu \mathrm{M} \mathrm{Ni}$ and $3.3 \mathrm{nM}$ Cd for Sudbury. In the most contaminated sites for both regions, dissolved $\mathrm{Cu}, \mathrm{Ni}$ and $\mathrm{Cd}$ concentrations were highly above these criteria. In the case of EX3 in Nunavik, this difference represents a factor of 4100,580 and 77 for $\mathrm{Cu}, \mathrm{Ni}$ and $\mathrm{Cd}$, respectively. In Sudbury, dissolved concentrations were slightly above the criteria for $\mathrm{Ni}(7 \mathrm{x})$ at $\mathrm{NC} 1$ and for $\mathrm{Cu}(9 \mathrm{x})$ and $\mathrm{Cd}(1.3 \mathrm{x})$ at NC2. 
3.3 Biofilm metal contents as a function of total dissolved and free ion concentrations

Several studies have found tight relationships between metal concentrations (labile or free metal ion) in ambient media and periphytic biofilm metal content (Bonnineau et al., 2020). These results were obtained based on both field and laboratory approaches: using microcosm experiments in the laboratory (Meylan et al., 2004; Mebane et al., 2020) or through field sampling at the river scale (Bonet et al., 2013; Faburé et al., 2015), at the watershed scale (Morin et al., 2008; Lavoie et al., 2012b) or at the inter-regional scale (Leguay et al., 2016; Laderriere et al., 2020). Correlation coefficients obtained through linear regression analyses of biofilm metal contents as a function of both dissolved concentrations and free metal concentrations are shown in Table 1. Except for Cd, taking into account Sudbury and Nunavik data at all pHs, statistically significant linear relationships were found between biofilm metal contents and their concentrations.

Coefficients of determination $\left(R^{2}\right.$ values) were comparable whether the biofilm metal content was expressed as a function of free metal concentrations or total dissolved metal concentrations. In the merged data set, the average ratio of $\mathrm{M}^{2+} / \mathrm{M}_{\mathrm{T}}$ was $18 \pm 30 \%, 76 \pm 17 \%$ and $71 \pm 16 \%$ for $\mathrm{Cu}, \mathrm{Ni}$ and $\mathrm{Cd}$, respectively. For each region, these ratios were $26 \pm 34 \%, 81 \pm 17 \%$ and $76 \pm$ $17 \%$ for Nunavik, and $3 \pm 5 \%, 68 \pm 13 \%$ and $62 \pm 8 \%$ for Sudbury. Nickel and Cd were mainly present as free ion species, reflecting their poor affinity for natural organic ligands (Mueller et al., 2012). The remaining predicted Ni complexes are mainly with carbonates ( $3 \%)$, sulfates ( $10 \%)$ and DOM ( $\sim 9 \%)$, whereas Cd binds to sulfates $(\sim 12 \%)$, chlorides $(\sim 7 \%)$ and DOM $(\sim 11 \%)$. Conversely, $\mathrm{Cu}$ is known to have a strong affinity for organic ligands and only a small proportion of $\mathrm{Cu}$ is usually present as the free ion (Mueller et al., 2012). Indeed, about $76 \pm 37 \%$ were calculated to bound to DOM in our samples. The remaining was principally bound by sulfates $(\sim 4 \%)$, carbonates $(\sim 1 \%)$ or present in the free form $(\sim 18 \%)$. However, in the case of Nunavik, these ratios are strongly affected by $\mathrm{pH}$. With decreasing $\mathrm{pHs}$, protons progressively bind to ligand functional groups which decreases binding site availability for metals and subsequently leads to 
an increase in the percentage of free metal ions. This point is important because, for $\mathrm{Cu}$ in the Nunavik data set, by excluding sites with pHs below 6, the percentages of free and DOM-bound Cu become $5 \pm 11 \%$ and $91 \pm 17 \%$, respectively. At circumneutral pHs, $\mathrm{Cu}$ is therefore scarcely present in its free form. Studies comparing field speciation to those predicted by WHAM in freshwaters report good agreements for metals that are known to weakly bind to DOM such as $\mathrm{Ni}$ and Cd (Unsworth et al., 2006; Lofts \& Tipping, 2011; Mueller et al., 2012). However, depending on the analytical method used to measure the free ion concentration, the speciation of metals that have high affinity for DOM (such as $\mathrm{Cu}$ ) were predicted with less accuracy. It was also observed that agreement between in situ measurements and WHAM predictions of the free metal ion tend to improve in lakes that had high total Cu concentrations. Additionally it was observed that there was excellent agreement when free copper concentrations were higher than $10^{-9} \mathrm{M}$ (Mueller et al., 2012). In the present study, free copper concentrations were calculated to be ranging between $\sim 10^{-12}$ to $\sim 10^{-4} \mathrm{M}$.

Despite these differences between total and free ion concentrations, these two concentrations are strongly correlated for $\mathrm{Cu}, \mathrm{Ni}$ and $\mathrm{Cd}$, with $\mathrm{R}^{2}$ values of $0.93,0.98$ and 0.97 , respectively (data not shown). As such, using the free metal ion concentrations do not improve the relationships between metal concentration in ambient media and bioaccumulated metal (Table 1), suggesting that there are no advantages of using the free ion concentration to predict metal accumulation in our samples. Such a result does not apply for all rivers. For instance, Lavoie et al. (2012) reported significant relationships between biofilm $\mathrm{Cu}$ content and free $\mathrm{Cu}$ concentrations, but not with total dissolved $\mathrm{Cu}$ concentrations. Indeed, despite total $\mathrm{Cu}$ concentrations being comparable across sampling sites (15 to $46 \mathrm{nM}$ ), a clear gradient of free ion concentrations was observed ( $10 \mathrm{pM}$ to $\sim 3 \mathrm{nM})$. The authors explained this result by the presence of a concentration gradient in DOC (1.9 to $5.8 \mathrm{mg} \mathrm{C} / \mathrm{L}$ ), resulting in an increase in $\mathrm{Cu}$ binding downstream of the mine tailings, which resulted in a decrease in $\mathrm{Cu}$ accumulation in biofilms. Because free metal ion concentrations are 
not always correlated to total dissolved metal concentrations, as it is the case in our study, using free metal concentration ensures that the present approach can be generalized on a larger geographical scale and therefore under various water chemistry conditions.

3.4 Relationships between metal accumulation and free metal ion concentration on a regional scale

Linear regressions were plotted for biofilm metal content as a function of free metal ion concentrations for the two sampled regions (Figure 3). Using an analysis of covariance (ANCOVA), the obtained slopes were found to be statistically different between the two regions and for the three metals studied ( $p$-values of $0.0005,0.038,0.013$ for $\mathrm{Cu}, \mathrm{Ni}$ and $\mathrm{Cd}$, respectively).

It is well known that environmental factors such as light or temperature are two of the main environmental parameters influencing primary production (Staehr and Sand-Jensen, 2006). Several studies have been conducted to assess the role of environmental fluctuations of parameters such as temperature (Morin et al., 2017), light duration (Corcoll et al., 2012), light intensity (Cheloni and Slaveykova, 2018) or, more generally, seasonal variability (Faburé et al., $2015)$ on the effects of metals upon biofilms. All of these studies highlight the fact that environmental parameters are likely to modify biofilm composition and thus potentially its response to metal exposure. Although no significant differences were observed in temperature (see Figure 2), it should be noted that the Sudbury area has significant forest cover, which can influence the amount of warming caused by solar radiation received at the water's surface. In contrast, the tundra of Nunavik has minimal shade coverage and the streams are very shallow. Significant temperature variations can therefore occur between a sunny or overcast day, or between day and night. Daily variation could thus occur and a single temperature measurement may not be sufficient to make accurate conclusions. Furthermore, these two regions are at different latitudes and light (intensity or spectral composition), which can modify the response of phototrophic aquatic organisms to metal exposure. Light can either directly affect the interactions between trace metals 
and photosynthetic microorganisms (i.e., metal toxicokinetics and toxicodynamics) or indirectly change ambient medium characteristics (Cheloni and Slaveykova, 2018). For instance, Cheloni et al. (2014) reported a change in Cu accumulation by Chlamydomonas reinhardtii when exposed to an altered ratio of PAR/UVR (photosynthetically active radiation/ultra-violet radiation) although no subcellular effects or growth inhibition were observed. The mine in Nunavik is located north of the $60^{\text {th }}$ parallel and this high latitude means that the biofilm could receive a light with a different PAR/UVR ratio than in the Sudbury region. Furthermore, the region has a photoperiod of approximately $19 / 5$ (day/night) at the summer solstice, compared to $15 / 9$ for the city of Greater Sudbury $\left(46^{\circ}\right.$ of latitude). Biofilms from Nunavik thus benefit from a greater photoperiod and a slightly different light spectral composition than biofilms from Sudbury. However, as mentioned by Cheloni and Slaveykova (2018), we still lack knowledge about these interactions and better understanding the mechanisms driving trace metal effects in aquatic environments and light irradiation will enable relevant lab-to-field extrapolation of metal exposure data.

The question is therefore whether a difference in communities induces a different bioaccumulation response. For instance, Pesce et al. (2018) exposed natural biofilms for 4 weeks to three different temperatures $\left(18,23\right.$, and $\left.28^{\circ} \mathrm{C}\right)$ in microcosms enriched with $\mathrm{Cu}(0.24 \mu \mathrm{M})$. Using different biomarkers, the authors studied the metal response of heterotrophic and autotrophic compartments of the biofilm (including microalgae, bacteria, fungi, and heterotrophic protists). They postulated that both the increase in temperature and the chronic $\mathrm{Cu}$ exposure modify microbial community structure, leading to changes in the capacity of phototrophic and heterotrophic communities to tolerate subsequent acute exposure to $\mathrm{Cu}$. However, although the authors highlighted the fact that the toxic response to $\mathrm{Cu}$ can vary greatly depending on the considered endpoint, they found no significant differences in internalized $\mathrm{Cu}$ concentrations, regardless of temperature and community changes. A similar conclusion was reached by Stewart et al. (2015) who exposed two different biofilm communities to $\mathrm{Pb}(97 \mathrm{nM})$ for 3 weeks to relate 
$\mathrm{Pb}$ distribution to biological effects in biofilm. The study concluded that $\mathrm{Pb}$ accumulation was independent of the community composition, with field data suggesting a similar conclusion. Indeed, both areas of the present study have been the subject of previous publications by Lavoie et al. $(2018,2019)$ on diatom assemblage structures. These studies demonstrated different diatom assemblage structures depending on the level and the type of contamination inside the same area and between the two regions. However, some similar species were found in both areas as Achnanthidium minutissimum, a species known to be tolerant to high metal concentrations (Luís et al., 2011; Morin et al., 2012; Leguay et al., 2016). In earlier work, Lavoie et al. (2012) collected water and biofilm samples in a single river once a month from May to October. Results showed similar accumulation of metals over time, despite the large variations in diatom species composition observed. Moreover, Leguay et al, (2016) demonstrated complementary findings with observed metal accumulation in biofilms from different regions (sites over $500 \mathrm{~km}$ apart) and among rivers with different physicochemical characteristics. In other words, field data suggest that, while environmental fluctuations or exposure to metals may alter the biofilm composition, metal content represents a robust biomarker for quantifying the metal exposure of biological communities.

3.5 Relationships between metal accumulation and free metal ion concentration on a global scale

For a similar free metal concentration, the biofilm metal concentrations were of the same order of magnitude in Sudbury and Nunavik, despite the distance $(\sim 1700 \mathrm{~km}$ apart) and the different physicochemical parameters of ambient surface waters. This result suggests that metal accumulation by biofilm in rivers can be compared between different ecosystems and ranges of free metal concentrations, although differences in uptake can be observed on a finer scale. Henceforth, we have combined the data from both regions to seek further trends. 
Sites with the highest free metal concentrations are characterized by low pHs and show internalized metal concentrations that do not follow the overall trend of the data (see yellow and red data in Figure 4). On the lower panel of Figure 4, the regressions statistically improve by excluding data with $\mathrm{pH}<6$ (higher $\mathrm{R}^{2}$ values) whereas the linear relationship between biofilm $\mathrm{Cd}$ content and free Cd ion concentration became significant $(p=0.0002)$. These results are in agreement with those published by Leguay et al. (2016) and Laderriere et al. (2020). The lower biofilm metal content at low pHs confirms the important role of $\mathrm{pH}$ and suggests an inhibition of metal uptake at high proton concentrations as highlighted in the BLM. A competitive effect is usually observed between $\mathrm{H}^{+}$ions and metals (Sánchez-Marín et al., 2018), which tends to decrease metal bioavailability and thus, toxicity. The possible effect of competing cations will be discussed below. Furthermore, acidity could also affect biofilm composition which may explain the lower biofilm metal content at $\mathrm{pH}<6$. For instance, Luís et al. (2014) showed a co-tolerance to metals and acidity of biofilms exposed to acidic treatments, contrasting with the higher sensitivity observed in biofilms exposed to alkaline treatments. In other words, the authors conclude that acidic environment exerts a selection pressure on the community composition which led to a greater tolerance to metal exposure. An acidic $\mathrm{pH}$ could therefore ameliorate the metal tolerance of a biofilm if the community has been pre-exposed (and has thus acclimated) to a complex chemical environment similar to what can be found in the vicinity of an operating mine. More recently, Luís et al. (2019) observed that biofilm communities affected by acid mine drainage and metal contamination had a greater ability to call upon antioxidant processes. This suggests that the adaptability of the biofilm communities to extreme acidic conditions may explain the low metal bioaccumulation at low $\mathrm{pH}$ levels. Nevertheless, these results obtained in the field confirm the universal potential of biofilm metal content to be used as a biomonitor at circumneutral pHs over time, on a large geographical scale.

\subsection{Competing effects}


Besides $\mathrm{pH}$, hardness is also known to modulate metal accumulation with high $\mathrm{Ca}^{2+}$ concentration, typically providing a protective effect (Deleebeeck et al., 2008). Moreover, trace metals can also show competitive effects between each other for uptake in algae as shown for $\mathrm{Cu}^{2+}$ (Flouty and Khalaf, 2015), $\mathrm{Ni}^{2+}$ (Worms and Wilkinson, 2007) and $\mathrm{Cd}^{2+}$ (Lavoie et al., 2012b). As presented in Eq. (6), the possible effect of competing cations can be evaluated by plotting the ratio of biofilm metal content to free metal ion concentration $\left([\mathrm{M}]_{\mathrm{Bio}} /\left[\mathrm{M}^{2+}\right]\right)$, as a function of competing cation concentrations. For an element with no expected competing effect, the $[\mathrm{M}]_{\mathrm{Bio}} /\left[\mathrm{M}^{2+}\right]$ ratio will be constant as a function of the competing cation concentration (a slope of zero). However, if the ratio decreases when a competing ion concentration increases (continuous decreasing trend), this would suggest that this ion may be modulating the biofilm metal accumulation.

The ratio of biofilm metal contents to free metal ion concentrations was then plotted as a function of the concentration of proton, calcium and magnesium ions for both regions (Figure 5). We used a Kendall's coefficient approach to measure the correlation of ratios $\left([\mathrm{M}]_{\mathrm{Bio}} /\left[\mathrm{M}^{2+}\right]\right)$ with the different ions in the water column. Kendall's correlation (coefficient marked as $\tau$ ) measures the dependence between two variables by ordinal association (based on rank correlation with values ranging from -1 to 1 ), and not only considering linear regression. The plots built as a function of proton concentration reveal the same trends for the three metals with ratio values relatively comparable for a proton concentration below $10^{-6} \mathrm{M}$. Beyond this concentration of $\mathrm{H}^{+}$, the three ratios follow a decreasing trend suggesting an important competing effect. This effect was more evident in the case of Nunavik compared to Sudbury, which is due to the quasi-absence of acidic $\mathrm{pHs}$ in the Sudbury data set. When plotted as a function of calcium, no uniform trend can be observed, although a plateau appears over the entire range of $\left[\mathrm{Ca}^{2+}\right]$ for data where $\mathrm{pH}>6$. In other words, $\mathrm{Ca}^{2+}$ appears to have no notable competing effect at neutral $\mathrm{pHs}$. However, the three ratios decrease when $\mathrm{pH}$ becomes acidic, reconfirming the key role of $\mathrm{pH}$. This trend is particularly 
evident for the Nunavik data set ( $\tau$ values of $-0.3,-0.3$ and -0.4 for $\mathrm{Cu}, \mathrm{Ni}$ and $\mathrm{Cd}$, respectively). With respect to the Sudbury data set, $\left[\mathrm{Ca}^{2+}\right]$ remains stable around $10^{-3} \mathrm{M}$, which makes it difficult to observe a trend. The calculated $\tau$ values are close to 0 except for Cu ratio $(\tau=-0.3)$, but no vertical trend is visible suggesting no competing effect despite important $\mathrm{Ca}^{2+}$ concentrations. These results are surprising because calcium is usually described as a key protective cation. For $\mathrm{Mg}^{2+}$, the ratios decrease when its concentration increase in the water column. The pattern is particularly marked in Nunavik ( $\tau=-0.7$ for the three metals studied) suggesting a protective effect. In the Sudbury data set, and as noticed for $\mathrm{Ca}^{2+}$ concentrations, the range of concentration is narrow resulting of $\tau$ values of 0.2 but with a variation of $[\mathrm{M}]_{\mathrm{Bio}} /\left[\mathrm{M}^{2+}\right]$ between $10^{1}$ and $10^{2} \mathrm{~L} / \mathrm{g}$. Nevertheless, for a $\mathrm{Ca}^{2+}$ concentration between $10^{-3.5}$ and $10^{-2.5} \mathrm{M}$, a difference in ratio is observed between the two regions. Indeed, for these concentrations, the Sudbury data set shows a ratio of approximately $10^{4} \mathrm{~L} / \mathrm{g}$ for $\mathrm{Cu}$ and $10^{1} \mathrm{~L} / \mathrm{g}$ for $\mathrm{Ni}$ and $\mathrm{Cd}$ compared to $10^{-2}$ and $10^{-1} \mathrm{~L} / \mathrm{g}$ in Nunavik. Nonetheless, sites with these low ratios are characterized by acidic $\mathrm{pHs}$. It is therefore difficult to distinguish whether these values can be explained by low $\mathrm{pH}$ values or by the fact that elements are correlated with each other, especially at low pHs. In Leguay et al. (2016), $[\mathrm{M}]_{\mathrm{Bio}} /\left[\mathrm{M}^{2+}\right]$ ratios showed a strong negative correlation with $\left[\mathrm{H}^{+}\right],\left[\mathrm{Ca}^{2+}\right]$ and $\left[\mathrm{Mg}^{2+}\right]$, demonstrating a competitive effect in the case of $\mathrm{Cd}$ and $\mathrm{Zn}$. Moreover, for $\mathrm{Cu}$ and $\mathrm{Pb}$, they observed a plateau followed by a continuously decreasing trend for both cations suggesting a competitive effect from a threshold concentration. However, for the range of $\mathrm{Ca}^{2+}$ concentrations found in Leguay et al. (2016), i.e. below $10^{-2} \mathrm{M}$ of magnitude, our findings are in agreement. In addition, we reported similar relationships in the same area of Nunavik in 2014 and 2015 (Laderriere et al., 2020). Indeed, results showed a gradual decrease in the ratio of $\mathrm{Cu}$, $\mathrm{Ni}$ and $\mathrm{Cd}$ biofilm contents when the concentrations of protons and magnesium ions increased in the water column. However, for calcium, data was quite scattered and no clear trend was observed as we also observed here. Interestingly, for metals common to these studies, the ratios have the same values of $[\mathrm{M}]_{\mathrm{Bio}} /\left[\mathrm{M}^{2+}\right]$ 
for circumneutral pHs, reaffirming the robustness of biofilm content as a pertinent biomarker of exposure despite large geographical scales, differences in type of ecosystem or biofilm characteristics.

In Figure 6, we analyzed the degree of association of each surface water parameter with the ratio of biofilm metal contents to its free metal concentrations for each region, independently. The upper panel presents three examples of opposing trends. In the case of $[\mathrm{Cu}]_{\mathrm{Bio}} /\left[\mathrm{Cu}^{2+}\right]$ as a function of $\left[\mathrm{Ni}^{2+}\right]$ (Nunavik data set), $\tau$ value is near $-1(\tau=-0.7)$ with data having a continuously decreasing trend. In other words, the ratio $[\mathrm{Cu}]_{\mathrm{Bio}} /\left[\mathrm{Cu}^{2+}\right]$ is decreasing as the $\left[\mathrm{Ni}^{2+}\right]$ is increasing. This indicates that Ni potentially acts as a strong competitor of $\mathrm{Cu}$ uptake in biofilm. With $[\mathrm{Ni}]_{\mathrm{Bio}} /\left[\mathrm{Ni}^{2+}\right]$ as a function of $\left[\mathrm{Ca}^{2+}\right]$ (Sudbury data set), $\tau$ value is near 0 indicating no trend and thus, no competing effect. The last case presents $[\mathrm{Cd}]_{\mathrm{Bio}} /\left[\mathrm{Cd}^{2+}\right]$ as a function of $\left[\mathrm{PO}_{4}{ }^{3-}\right]$ (Nunavik data set). Data follow an increasing trend, which leads to a positive $\tau$ value (0.6). Biofilm metal content is thus positively correlated with this element. Despite our large number of samples, a greater variety of sampling sites incorporating physicochemical characteristics and the degree of anthropogenic pressure is needed to complete the analyses. Indeed, the Nunavik data set shows many auto-correlations between parameters, which impede the correct distinction between interactions. For example, if one site had a high concentration of dissolved $\mathrm{Cu}$, which occurs in many cases in the Nunavik data set, the dissolved competitor concentrations were also high. This point makes interpretation difficult because, using copper as an example, the copper concentrations $\left([\mathrm{Cu}]_{\mathrm{T}}\right.$ or $\left.\left[\mathrm{Cu}^{2+}\right]\right)$ show a strong correlation with other metals. The biofilm metal content $[\mathrm{Cu}]_{\text {Bio }}$ is thus correlated to $\left[\mathrm{Cu}^{2+}\right]$, but also to other $\left[\mathrm{M}^{\mathrm{z}}\right]$. As such, in the case of auto-correlated metals, ratios only indicate the correlation between the metals themselves. This explains why in the Nunavik data set, $[\mathrm{Ni}]_{\mathrm{Bio}} /\left[\mathrm{Ni}^{2+}\right]$ shows a Kendall's coefficient equal $(\tau=-0.8)$ with $\left[\mathrm{Cu}^{2+}\right],\left[\mathrm{Mn}^{2+}\right],\left[\mathrm{Cd}^{2+}\right]$, and to major cation concentrations $\left(\tau=-0.7\right.$ with $\left[\mathrm{Ca}^{2+}\right]$ or $\left.\left[\mathrm{Mg}^{2+}\right]\right)$. In 2014 and 2015 , data collected at the same sites in Nunavik showed similar patterns and auto-correlations (Laderriere et al., 2020). However, the 
results found in the present study confirm that the biofilm metal content is consistent over several years. The Sudbury data set is more appropriate to model competitive interactions and extract binding constants for biofilm using a BLM approach. Indeed, despite important mining activities, this data set incorporates more variability in stressors (e.g. urban context) and conditions (e.g. input of other rivers along the Junction Creek). Therefore, this region is less exposed to conditions specific to mining activities, such as acidic $\mathrm{pH}$ or very high concentrations of several metals at the same time. We will thus focus the rest of the discussion on the correlation matrix of the Sudbury data set. However, it is important to keep in mind that a $\tau$ value between -0.2 and 0.2 could represent data that do not necessarily form a decreasing pattern on an interesting range of concentrations. For instance, $[\mathrm{Mg}]$ are tightly grouped around $10^{-3} \mathrm{M}$ (see Figure 2) and $[\mathrm{Cu}]_{\mathrm{Bio}} /\left[\mathrm{Cu}^{2+}\right]$ only vary by two orders of magnitude in Sudbury, which represents narrow ranges of variation lacking in heterogeneity in our sampling sites (see Figure 5). All the competitive effects discussed in the rest of this section showed a decreasing trend of $[\mathrm{M}]_{\mathrm{Bio}} /\left[\mathrm{M}^{\mathrm{z}+}\right]$ as a function of the competitor with $\tau$ values between -0.3 and -1 .

On the lower panel of Figure 6, a matrix correlation approach was used to simplify the representation. With respect to divalent metals, the ratio $[\mathrm{Cu}]_{\mathrm{Bio}} /\left[\mathrm{Cu}^{2+}\right]$ has a negative $\tau$ value with $\mathrm{Ca}(\tau=-0.3)$, indicating a slight competing effect. Moreover, the $[\mathrm{Cu}]_{\mathrm{Bio}} /\left[\mathrm{Cu}^{2+}\right]$ ratio is not negatively correlated to $\left[\mathrm{Ni}^{2+}\right]$ and $\left[\mathrm{Cd}^{2+}\right](\tau=0)$ or other divalent metals (except for $\mathrm{Pb}$ but the $\tau$ value is superior to -0.3$)$. On the other hand, $[\mathrm{Ni}]_{\mathrm{Bio}} /\left[\mathrm{Ni}^{2+}\right]$ shows a negative $\tau$ value (inferior to -0.3 ) with $\left[\mathrm{Mn}^{2+}\right],\left[\mathrm{Cu}^{2+}\right],\left[\mathrm{Zn}^{2+}\right]$ and $\left[\mathrm{Cd}^{2+}\right]$. These results are in agreement with the observations of Flouty \& Khalaf (2015). The authors measured the uptake of $\mathrm{Ni}, \mathrm{Pb}$ and $\mathrm{Cu}$ by the unicellular green alga Chlamydomonas reinhardtii in the presence of various concentrations of $\mathrm{Pb}^{2+}$ and $\mathrm{Cu}^{2+}$. $\mathrm{Cu}_{\text {was }}$ shown to strongly compete with $\mathrm{Ni}$ uptake and $\mathrm{Cu}^{2+}$ was shown to have a high binding affinity for both $\mathrm{Ni}$ and $\mathrm{Cu}$ transport sites. Furthermore, internalization fluxes of $\mathrm{Cu}$ remained constant in the absence and presence of $\mathrm{Ni}^{2+}$, implying that $\mathrm{Ni}$ had no effect on the uptake of $\mathrm{Cu}$. This is consistent 
with our results with $[\mathrm{Cu}]_{\mathrm{Bio}} /\left[\mathrm{Cu}^{2+}\right]$ as a function of $\left[\mathrm{Ni}^{2+}\right]$ having a $\tau=0$. Furthermore, Worms \& Wilkinson (2007) observed that the Ni uptake by C. reinhardtii was strongly affected by $\mathrm{Zn}^{2+}$ and $\mathrm{Cu}^{2+}$ but only slightly by $\mathrm{Mn}^{2+}$ and $\mathrm{Cd}^{2+}$. They showed that $\mathrm{Ni}$ uptake decreased by $70 \%$ with a 5fold greater concentration of $\mathrm{Cu}$, while the same concentration of $\mathrm{Zn}$ decreased Ni uptake by $60 \%$. Conversely, $\mathrm{Cd}^{2+}$ had only a small effect on $\mathrm{Ni}$ uptake $\left(10 \%\right.$ decrease) while $\mathrm{Mn}^{2+}$ had no significant effect. Our results are in agreement $\left(\tau=-0.3,-0.5,-0.5\right.$ for $\mathrm{Cu}^{2+}, \mathrm{Zn}^{2+}$ and $\mathrm{Cd}^{2+}$, respectively), although, $\mathrm{Mn}^{2+}$ seems to have a slight competing effect according to our data $(\tau=-$ $0.3)$. Finally, the $\mathrm{Cd}$ ratio shows negative $\tau$ values with $\left[\mathrm{Cu}^{2+}\right](\tau=-0.3)$ and $\left[\mathrm{Zn}^{2+}\right]$ but the value in the case of the latter remains relatively low $(\tau=-0.2)$. Lavoie et al. (2012) confirmed the strong protective effect of $\mathrm{Zn}^{2+}$ on $\mathrm{Cd}$ accumulation in C. reinhardtii. Regarding trivalent metals, the Sudbury data set shows too narrow a range of Al variation in terms of free concentrations to make conclusions (Figure 2). For Fe, only $[\mathrm{Cu}]_{\mathrm{Bio}} /\left[\mathrm{Cu}^{2+}\right]$ ratios show a trend $(\tau=-0.5)$. Indeed, $[\mathrm{Ni}]_{\mathrm{Bio}} /\left[\mathrm{Ni}^{2+}\right]$ and $[\mathrm{Cd}]_{\mathrm{Bio}} /\left[\mathrm{Cd}^{2+}\right]$ were not correlated to Fe. This suggests a possible competing effect for $\mathrm{Cu}$. Kochoni \& Fortin (2019) suggested that low concentrations of $\mathrm{Fe}^{3+}$ (from $10^{-19.0}$ to $10^{-17.6} \mathrm{M}$ ) could increase $\mathrm{Cu}^{2+}$ uptake and toxicity in $\mathrm{C}$. reinhardtii. Calculated free $\mathrm{Fe}^{3+}$ ion concentrations were ranging from $10^{-21}$ to $10^{-15} \mathrm{M}$ in our Sudbury data set. On the other hand, for $\mathrm{Ni}$ and $\mathrm{Cd}$, and again with C. reinhardtii, Worms \& Wilkinson (2007) showed that high concentrations of Fe $(0.25 \mu M)$ had no effect on Ni uptake, and Lavoie et al. (2012) demonstrated that a 100-fold increase in free $\mathrm{Fe}^{3+}$ did not affect $\mathrm{Cd}$ uptake or toxicity. Overall, the relationships observed in the field are coherent with those obtained in the laboratory with model organisms. However, further investigations will be necessary to clarify the effect of each competitor while incorporating a greater variety of exposure conditions and not necessarily in a mining context, to avoid or reduce auto-correlations. Indeed, if the Sudbury data set had less auto-correlations than observed for the Nunavik data, the dynamic range of concentrations was smaller for almost all elements present in the water column (Figure 2). Moreover, this auto-correlation in the Nunavik data set did not allow 
us to compare the effects of ion competition between the two regions. Indeed, a difference at this level could explain the differences in bioaccumulation slopes observed between regions.

\section{Conclusions}

This study investigated the robustness of biofilm metal content as a tool for the biomonitoring of metal exposure over large geographical scales. Our results confirm that the concentration of free metals in the water explains a large amount of the metal concentrations in biofilms at circumneutral pHs. Significant linear relationships were also found with dissolved metal concentrations. However, this finding could be related to our specific mining context leading to auto-correlation between total and free metal concentrations. Using free metal concentrations ensures that the approach can be generalized to various water chemistry conditions. Furthermore, $\mathrm{pH}$ appears to play a key role in the metal accumulation response of biofilm. Results were highly consistent from one month to the other in the case of Nunavik, and between the two regions studied, despite the $\sim 1700 \mathrm{~km}$ distance between them. Indeed, biofilm metal contents normalized to ambient metal ion concentrations were consistent despite differences in climate, ecosystems and anthropogenic pressures. On one hand, the results suggest that the accumulation of metals by biofilm is sensitive to the protective effect of magnesium and protons. On the other hand, we did not observe any evidence of the effect of calcium as a competitor for $\mathrm{Ni}$, $\mathrm{Cu}$ and $\mathrm{Cd}$ bioaccumulation, with its effect being $\mathrm{pH}$ related. The auto-correlation of metals within the Nunavik data set made it difficult to analyze the interactions between elements in the water column with the internalization of metals. Despite a lower range of observed metal concentrations as compared to those in Nunavik, the Sudbury data set allowed for comparing the protective effects of competitive ions with those found in the literature, notably in studies using unicellular algae in single or mixture exposures. However, we were unable to tease out the effects of ionic competition between the two regions, which could have explained the differences in slopes observed in 
bioaccumulation regressions. A greater variety in terms of physicochemical characteristics and degree of anthropogenic pressure will be necessary to distinguish interactions correctly. Finally, results found in the present study were highly consistent with those already published with similar normalized biofilm metal contents for the three metals studied at neutral $\mathrm{pH}$ values. This finding is important because it suggests the universal potential of biofilm metal content as a proxy for metal bioavailability, despite large geographical scales in lotic ecosystems.

Future work will need to focus on having a wider range of physicochemical conditions to avoid auto-correlation of data found here due to the typical water composition found in a mining context. This will allow for better discrimination of interactions between biofilm metal content and elements in the water column. This will be helpful to predict biofilm metal content by integrating some of the complexity of natural waters in a BLM based model. A multi-metric approach that would include the inherent characteristics of the biofilm (structure, community, tolerance) could also be useful to predict the degree of stress caused by metal exposure as well as the effects of environmental factors in a biomonitoring perspective. 


\section{Acknowledgements}

We acknowledge the helpful assistance of Louise-Emmanuelle Paris and Sandra Kim Tiam during field work. We also thank the Nunavik Nickel mine staff for their participation and access to their facilities. Special thanks to Emmanuel Demard and Jimmy Poulin for their help in preparing the maps and Scott Hepditch for language assistance. This study was funded by the Fonds de recherche du Québec - Nature et technologies (FRQNT; grant number 2014-MI-183237). Claude Fortin is supported by the Canada Research Chair Program (grant number 950-231107). Séverine Le Faucheur is supported by the Research Partnership Chair E2S-UPPA-Total-Rio Tinto (ANR16-IDEX-0002). Finally, we thank the Institut National de la Recherche Scientifique (INRS) laboratory technicians for their help in performing chemical analyses of water samples.

\section{References}

Adams, W., Blust, R., Dwyer, R., Mount, D., Nordheim, E., Rodriguez, P.H., Spry, D., 2020. Bioavailability assessment of metals in freshwater environments: a historical review. Environ. Toxicol. Chem. 39, 48-59. https://doi.org/10.1002/etc.4558

Battin, T.J., Besemer, K., Bengtsson, M.M., Romani, A.M., Packmann, A.I., 2016. The ecology and biogeochemistry of stream biofilms. Nat. Rev. Microbiol. 14, 251-263. https://doi.org/10.1038/nrmicro.2016.15

Bonet, B., Corcoll, N., Acuňa, V., Sigg, L., Behra, R., Guasch, H., 2013. Seasonal changes in antioxidant enzyme activities of freshwater biofilms in a metal polluted Mediterranean stream. Sci. Total Environ. 444, 60-72. https://doi.org/10.1016/j.scitotenv.2012.11.036

Bonnineau, C., Artigas, J., Chaumet, B., Dabrin, A., Faburé, J., Ferrari, B.J.D., Lebrun, J.D., Margoum, C., Mazzella, N., Miège, C., Morin, S., Uher, E., Babut, M., Pesce, S., 2020. Role 
of biofilms in contaminant bioaccumulation and trophic transfer in aquatic ecosystems: current state of knowledge and future challenges. Rev. Environ. Contam. Toxicol. 253, 115153. https://doi.org/10.1007/398_2019_39

Bradac, P., Wagner, B., Kistler, D., Traber, J., Behra, R., Sigg, L., 2010. Cadmium speciation and accumulation in periphyton in a small stream with dynamic concentration variations. Environ. Pollut. 158, 641-648. https://doi.org/10.1016/j.envpol.2009.10.031

Cadmus, P., Clements, W.H., Williamson, J.L., Ranville, J.F., Meyer, J.S., Gutiérrez Ginés, M.J., 2016. The use of field and mesocosm experiments to quantify effects of physical and chemical stressors in mining-contaminated streams. Environ. Sci. Technol. 50, 7825-7833. https://doi.org/10.1021/acs.est.6b01911

Campbell, P.G.C., Fortin, C., 2013. Biotic Ligand Model. J.-F. Férard, C. Blaise (eds.), Encycl. Aquat. Ecotoxicol. 2, 237-245. https://doi.org/10.1007/978-94-007-5704-2

Canadian Council of Ministers for the Environment, 2014. Canadian water quality guidelines for the protection of aquatic life. [WWW Document]. URL https://www.ccme.ca/en/about/index.html

Chaumet, B., Morin, S., Hourtané, O., Artigas, J., Delest, B., Eon, M., Mazzella, N., 2019. Flow conditions influence diuron toxicokinetics and toxicodynamics in freshwater biofilms. Sci. Total Environ. 652, 1242-1251. https://doi.org/10.1016/j.scitotenv.2018.10.265

Cheloni, G., Cosio, C., Slaveykova, V.I., 2014. Antagonistic and synergistic effects of light irradiation on the effects of copper on Chlamydomonas reinhardtii. Aquat. Toxicol. 155, 275282. https://doi.org/10.1016/j.aquatox.2014.07.010

Cheloni, G., Slaveykova, V.I., 2018. Combined effects of trace metals and light on photosynthetic $\begin{array}{llll}\text { microorganisms in aquatic environment. } & \text { Environments. }\end{array}$ 
https://doi.org/10.3390/environments5070081

Corcoll, N., Bonet, B., Leira, M., Montuelle, B., Tlili, A., Guasch, H., 2012. Light history influences the response of fluvial biofilms to $\mathrm{Zn}$ exposure. J. Phycol. 48, 1411-1423. https://doi.org/10.1111/j.1529-8817.2012.01223.x

Crémazy, A., Campbell, P.G.C., Fortin, C., 2013. The biotic ligand model can successfully predict the uptake of a trivalent ion by a unicellular alga below $\mathrm{pH} 6.50$ but not above: Possible role of hydroxo-species. Environ. Sci. Technol. 47, 2408-2415. https://doi.org/10.1021/es3038388

Deleebeeck, N.M.E., Schamphelaere, K.A.C.D., Janssen, C.R., 2008. A novel method for predicting chronic nickel bioavailability and toxicity to Daphnia magna in artificial and natural waters. Environ. Toxicol. Chem. 27, 2097-2107. https://doi.org/10.1897/07-579.1

Erickson, R.J., 2013. The biotic ligand model approach for addressing effects of exposure water chemistry on aquatic toxicity of metals: Genesis and challenges. Environ. Toxicol. Chem. 32, 1212-1214. https://doi.org/10.1002/etc.2222

Faburé, J., Dufour, M., Autret, A., Uher, E., Fechner, L.C., 2015. Impact of an urban multi-metal contamination gradient: Metal bioaccumulation and tolerance of river biofilms collected in $\begin{array}{llll}\text { different } & \text { seasons. } & \text { Aquat. } & \text { Toxicol. }\end{array}$ https://doi.org/10.1016/j.aquatox.2014.12.014

Flemming, H.C., Wingender, J., 2010. The biofilm matrix. Nat. Rev. Microbiol. 8, 623-633. https://doi.org/10.1038/nrmicro2415

Flouty, R., Khalaf, G., 2015. Role of $\mathrm{Cu}$ and $\mathrm{Pb}$ on Ni bioaccumulation by Chlamydomonas reinhardtii: validation of the biotic ligand model in binary metal mixtures. Ecotoxicol. Environ. Saf. 113, 79-86. https://doi.org/10.1016/j.ecoenv.2014.11.022 
Guasch, H., Artigas, J., Bonet, B., Bonnineau, C., Canals, O., Corcoll, N., 2016. The use of biofilms to assess the effects of chemicals on freshwater ecosystems, In Aquatic Biofilms: Ecology, Water Quality and Wastewater Treatment. Caister Academic Press, Spain. https://doi.org/10.21775/9781910190173.06

Guasch, H., Ginebreda, A., Geiszinger, A., 2012. Emerging and priority pollutants in river, In Handboo. ed, The Handbook of Environmental Chemistry. Springer. https://doi.org/10.1016/0143-1471(82)90111-8

Kalin, M., Fyson, A., Wheeler, W.N., 2006. The chemistry of conventional and alternative treatment systems for the neutralization of acid mine drainage. Sci. Total Environ. 366, 395408. https://doi.org/10.1016/j.scitotenv.2005.11.015

Kim, K.S., Funk, D.H., Buchwalter, D.B., 2012. Dietary (periphyton) and aqueous Zn bioaccumulation dynamics in the mayfly Centroptilum triangulifer. Ecotoxicology 21, 22882296. https://doi.org/10.1007/s10646-012-0985-1

Kochoni, E., Fortin, C., 2019. Iron modulation of copper uptake and toxicity in a green alga (Chlamydomonas reinhardtii). Environ. Sci. Technol. 53, 6539-6545. https://doi.org/10.1021/acs.est.9b01369

Laderriere, V., Paris, L.E., Fortin, C., 2020. Proton competition and free ion activities drive cadmium, copper, and nickel accumulation in river biofilms in a nordic ecosystem. Environments 7, 1-13. https://doi.org/10.3390/environments7120112

Lavoie, I., Lavoie, M., Fortin, C., 2012. A mine of information: Benthic algal communities as biomonitors of metal contamination from abandoned tailings. Sci. Total Environ. 425, 231241. https://doi.org/10.1016/j.scitotenv.2012.02.057

Lavoie, I., Morin, S., Laderriere, V., Fortin, C., 2018. Freshwater diatoms as indicators of 
Combined long-term mining and urban stressors in Junction Creek (Ontario, Canada). Environments 5, 30. https://doi.org/10.3390/environments5020030

Lavoie, I., Morin, S., Laderriere, V., Paris, L.-E., Fortin, C., 2019. Assessment of diatom assemblages in close proximity to mining activities in Nunavik, Northern Quebec (Canada). Environments 6, 74. https://doi.org/10.3390/environments6060074

Lavoie, M., Campbell, P.G.C., Fortin, C., 2012a. Extending the biotic ligand model to account for positive and negative feedback interactions between cadmium and zinc in a freshwater alga. Environ. Sci. Technol. 46, 12129-12136. https://doi.org/10.1021/es302512r

Lavoie, M., Fortin, C., Campbell, P.G.C., 2012b. Influence of essential elements on cadmium uptake and toxicity in a unicellular green alga: the protective effect of trace zinc and cobalt concentrations. Environ. Toxicol. Chem. 31, 1445-1452. https://doi.org/10.1002/etc.1855

Lebrun, J.D., Geffard, O., Urien, N., François, A., Uher, E., Fechner, L.C., 2015. Seasonal variability and inter-species comparison of metal bioaccumulation in caged gammarids under urban diffuse contamination gradient: Implications for biomonitoring investigations. Sci. Total Environ. 511, 501-508. https://doi.org/10.1016/j.scitotenv.2014.12.078

Leguay, S., Lavoie, I., Levy, J.L., Fortin, C., 2016. Using biofilms for monitoring metal contamination in lotic ecosystems: The protective effects of hardness and $\mathrm{pH}$ on metal bioaccumulation. Environ. Toxicol. Chem. 35, 1489-1501. https://doi.org/10.1002/etc.3292

Lofts, S., Tipping, E., 2011. Assessing WHAM / Model VII against field measurements of free metal ion concentrations : model performance and the role of uncertainty in parameters and inputs. Environ. Chem. 8, 501-516. https://doi.org/10.1071/EN11049

Lopez, A.R., Funk, D.H., Buchwalter, D.B., 2017. Arsenic (V) bioconcentration kinetics in freshwater macroinvertebrates and periphyton is influenced by $\mathrm{pH}$. Environ. Pollut. 224, 82- 
88. https://doi.org/10.1016/j.envpol.2016.12.066

Luís, A.T., Bonet, B., Corcoll, N., Almeida, S.F.P., Da Silva, E.F., Figueira, E., Guasch, H., 2014. Experimental evaluation of the contribution of acidic $\mathrm{pH}$ and Fe concentration to the structure, function and tolerance to metals ( $\mathrm{Cu}$ and $\mathrm{Zn}$ ) exposure in fluvial biofilms. Ecotoxicology 23, 1270-1282. https://doi.org/10.1007/s10646-014-1270-2

Luís, A.T., Teixeira, M., Durães, N., Pinto, R., Almeida, S.F.P., da Silva, E.F., Figueira, E., 2019. Extremely acidic environment: Biogeochemical effects on algal biofilms. Ecotoxicol. Environ. Saf. 177, 124-132. https://doi.org/10.1016/j.ecoenv.2019.04.001

Luís, A.T., Teixeira, P., Almeida, S.F.P., Matos, J.X., Da Silva, E.F., 2011. Environmental impact of mining activities in the Lousal area (Portugal): Chemical and diatom characterization of metal-contaminated stream sediments and surface water of Corona stream. Sci. Total Environ. 409, 4312-4325. https://doi.org/10.1016/j.scitotenv.2011.06.052

Martyniuk, M.A.C., Couture, P., Tran, L., Beaupré, L., Urien, N., Power, M., 2020. A seasonal comparison of trace metal concentrations in the tissues of Arctic charr (Salvelinus alpinus) in Northern Québec, Canada. Ecotoxicology 29, 1327-1346. https://doi.org/10.1007/s10646020-02248-7

Mebane, C.A., Schmidt, T.S., Miller, J.L., Balistrieri, L.S., 2020. Bioaccumulation and toxicity of cadmium, copper, nickel, and zinc and their mixtures to aquatic insect communities. Environ. Toxicol. Chem. 39, 812-833. https://doi.org/10.1002/etc.4663

Meylan, S., Behra, R., Sigg, L., 2004. Influence of metal speciation in natural freshwater on bioaccumulation of copper and zinc in periphyton: A microcosm study. Environ. Sci. Technol. 38, 3104-3111. https://doi.org/10.1021/es034993n

Morel, F.M.M., 1983. Principles and applications of aquatic chemistry, John Wiley \& Sons, Inc. : 
Somerset, N.J.

Morin, S., Duong, T.T., Dabrin, A., Coynel, A., Herlory, O., Baudrimont, M., Delmas, F., Durrieu, G., Schäfer, J., Winterton, P., Blanc, G., Coste, M., 2008. Long-term survey of heavy-metal pollution, biofilm contamination and diatom community structure in the Riou Mort watershed, $\begin{array}{llll}\text { South-West } & \text { France. } & \text { Environ. } & \text { Pollut. }\end{array}$ https://doi.org/10.1016/j.envpol.2007.04.023

Morin, S., Lambert, A.S., Rodriguez, E.P., Dabrin, A., Coquery, M., Pesce, S., 2017. Changes in copper toxicity towards diatom communities with experimental warming. J. Hazard. Mater. 334, 223-232. https://doi.org/10.1016/j.jhazmat.2017.04.016

Mueller, K.K., Lofts, S., Fortin, C., Campbell, P.G.C., 2012. Trace metal speciation predictions in natural aquatic systems: Incorporation of dissolved organic matter (DOM) spectroscopic quality. Environ. Chem. 9, 356-368. https://doi.org/10.1071/EN11156

Neury-Ormanni, J., Doose, C., Majdi, N., Vedrenne, J., Traunspurger, W., Morin, S., 2020. Selective grazing behaviour of chironomids on microalgae under pesticide pressure. Sci. Total Environ. 730, 138673. https://doi.org/10.1016/j.scitotenv.2020.138673

Perdue, E.M., Ritchie, J.D., 2003. Dissolved organic matter in freshwaters, in: Heinrich D.H., Turekian, K.K. (Eds.), Treatise on Geochemistry. Elsevier, pp. 273-318. https://doi.org/10.1016/B0-08-043751-6/05080-5

Pesce, S., Lambert, A.-S., Morin, S., Foulquier, A., Coquery, M., Dabrin, A., 2018. Experimental warming differentially influences the vulnerability of phototrophic and heterotrophic periphytic communities to copper toxicity. Front. Microbiol. 9, 1424. https://doi.org/10.3389/fmicb.2018.01424

Sánchez-Marín, P., Liu, F., Chen, Z., Fortin, C., Campbell, P.G.C., 2018. Microalgal-driven pH 
changes in the boundary layer lead to apparent increases in $\mathrm{Pb}$ internalization by a unicellular alga in the presence of citrate. Limnol. Oceanogr. 63, 1328-1339. https://doi.org/10.1002//no.10774

Staehr, P.A., Sand-Jensen, K.A.J., 2006. Seasonal changes in temperature and nutrient control of photosynthesis, respiration and growth of natural phytoplankton communities. Freshw. Biol. 51, 249-262. https://doi.org/10.1111/j.1365-2427.2005.01490.x

Stewart, T.J., Behra, R., Sigg, L., 2015. Impact of chronic lead exposure on metal distribution and biological effects to periphyton. Environ. Sci. Technol. 49, 5044-5051. https://doi.org/10.1021/es505289b

Tercier-Waeber, M.-L., Stoll, S., Slaveykova, V.I., 2012. Trace metal behavior in surface waters: Emphasis on dynamic speciation, sorption processes and bioavailability. Arch. des Sci. 65, $119-142$.

Tolotti, R., Consani, S., Carbone, C., Vagge, G., Capello, M., Cutroneo, L., 2019. Benthic diatom community response to metal contamination from an abandoned $\mathrm{Cu}$ mine: Case study of the Gromolo Torrent (Italy). J. Environ. Sci. (China) 75, 233-246. https://doi.org/10.1016/j.jes.2018.03.034

Unsworth, E.R., Warnken, K.W., Zhang, H., Davison, W., Black, F., Buffle, J., Cao, J., Cleven, R., Galceran, J., Gunkel, P., Kalis, E., Kistler, D., Van Leeuwen, H.P., Martin, M., Noël, S., Nur, Y., Odzak, N., Puy, J., Van Riemsdijk, W., Sigg, L., Temminghoff, E., Tercier-Waeber, M. Lou, Toepperwien, S., Town, R.M., Weng, L., Xue, H., 2006. Model predictions of metal speciation in freshwaters compared to measurements by in situ techniques. Environ. Sci. Technol. 40, 1942-1949. https://doi.org/10.1021/es051246c

Weber, L.P., Dubé, M.G., Rickwood, C.J., Driedger, K., Portt, C., Brereton, C., Janz, D.M., 2008. Effects of multiple effluents on resident fish from Junction Creek, Sudbury, Ontario. 
Ecotoxicol. Environ. Saf. 70, 433-445. https://doi.org/10.1016/j.ecoenv.2007.08.001

Worms, I.A.M., Wilkinson, K.J., 2007. Ni uptake by a green alga. 2. Validation of equilibrium models for competition effects. Environ. Sci. Technol. 41, 4264-4270. https://doi.org/10.1021/es0630341

Xie, L., Funk, D.H., Buchwalter, D.B., 2010. Trophic transfer of Cd from natural periphyton to the grazing mayfly Centroptilum triangulifer in a life cycle test. Environ. Pollut. 158, 272-277. https://doi.org/10.1016/j.envpol.2009.07.010 
Table 1: Coefficients of determination ( $R^{2}$ values) from linear regression analyses of accumulated metals $\left([\mathrm{M}]_{\text {Bio }}\right)$ as a function of dissolved or free metal concentration. Significance threshold values are: $p \leq$ 0.0001 "****"; $p \leq 0.001$ "***"; $p \leq 0.01$ "**"; $p \leq 0.05$ "*"; $p>0.05$ "ns". All data refers to data from Nunavik and Sudbury together.

\begin{tabular}{|c|c|c|c|c|c|c|}
\hline Metal form & \multicolumn{2}{|c|}{ All data } & \multicolumn{2}{|c|}{ Nunavik } & \multicolumn{2}{|c|}{ Sudbury } \\
\hline \multicolumn{7}{|c|}{ All pHs } \\
\hline Dissolved Cu & 0.35 & $* \star \star *$ & 0.48 & $* * * *$ & 0.77 & $* * * *$ \\
\hline Free $\mathrm{Cu}^{2+}$ & 0.41 & $* * * *$ & 0.58 & $* * * *$ & 0.62 & $* * * *$ \\
\hline Dissolved Ni & 0.16 & $* *$ & 0.24 & $* *$ & 0.54 & $* * *$ \\
\hline Free $\mathrm{Ni}^{2+}$ & 0.14 & $* *$ & 0.27 & $* *$ & 0.50 & $* * *$ \\
\hline Dissolved Cd & $1.9 \times 10^{-4}$ & ns & $2.6 \times 10^{-3}$ & ns & 0.35 & ** \\
\hline Free $\mathrm{Cd}^{2+}$ & $7.1 \times 10^{-5}$ & ns & $2.3 \times 10^{-5}$ & ns & 0.33 & $* *$ \\
\hline \multicolumn{7}{|c|}{ Only pH > 6} \\
\hline Dissolved Cu & 0.63 & $* * * *$ & 0.71 & $* * * *$ & 0.79 & $* * * *$ \\
\hline Free $\mathrm{Cu}^{2+}$ & 0.57 & $* * * *$ & 0.74 & $* * * *$ & 0.60 & $* * *$ \\
\hline Dissolved Ni & 0.62 & $* * * *$ & 0.54 & $* * * *$ & 0.70 & $* * * *$ \\
\hline Free $\mathrm{Ni}^{2+}$ & 0.55 & $* * * *$ & 0.56 & $* * * *$ & 0.70 & $* * * *$ \\
\hline Dissolved Cd & 0.38 & $* * * *$ & 0.37 & $* *$ & 0.35 & $* *$ \\
\hline Free $\mathrm{Cd}^{2+}$ & 0.30 & $* * *$ & 0.37 & $* *$ & 0.38 & ** \\
\hline
\end{tabular}



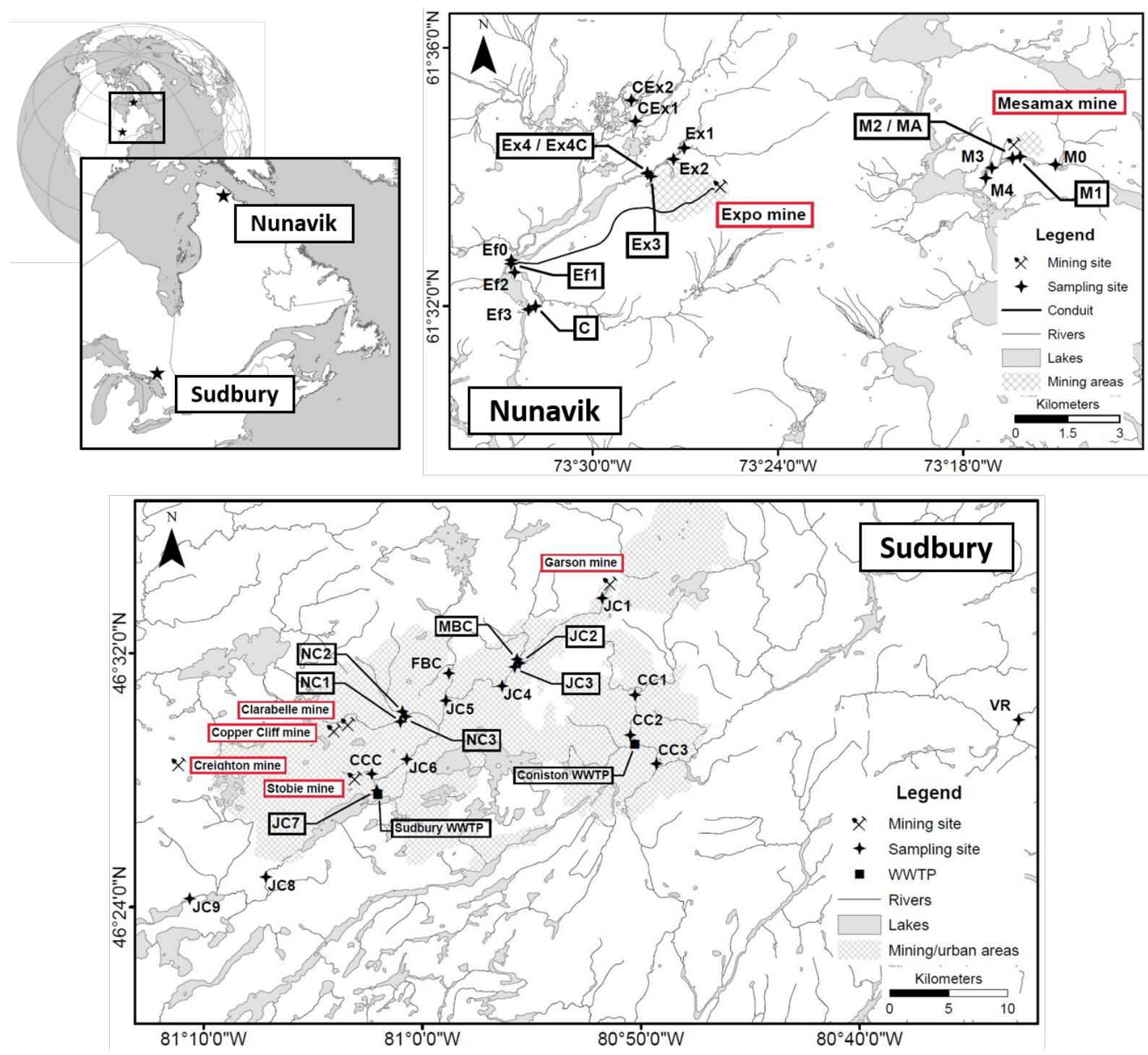

Figure 1: Sampling sites in Nunavik (QC) and in the Sudbury area (ON) in Canada. The shaded zones (light gray) represent in both cases the mining or urban areas. WWTP $=$ wastewater treatment plant; JC $=$ Junction Creek; $\mathrm{MBC}=$ Maley Branch Creek; VR = Veuve River; FBC = Frood Branch Creek; $C \mathrm{C}=$ Coniston Creek; NC = Nolin Creek; CCC = Copper Cliff Creek. 

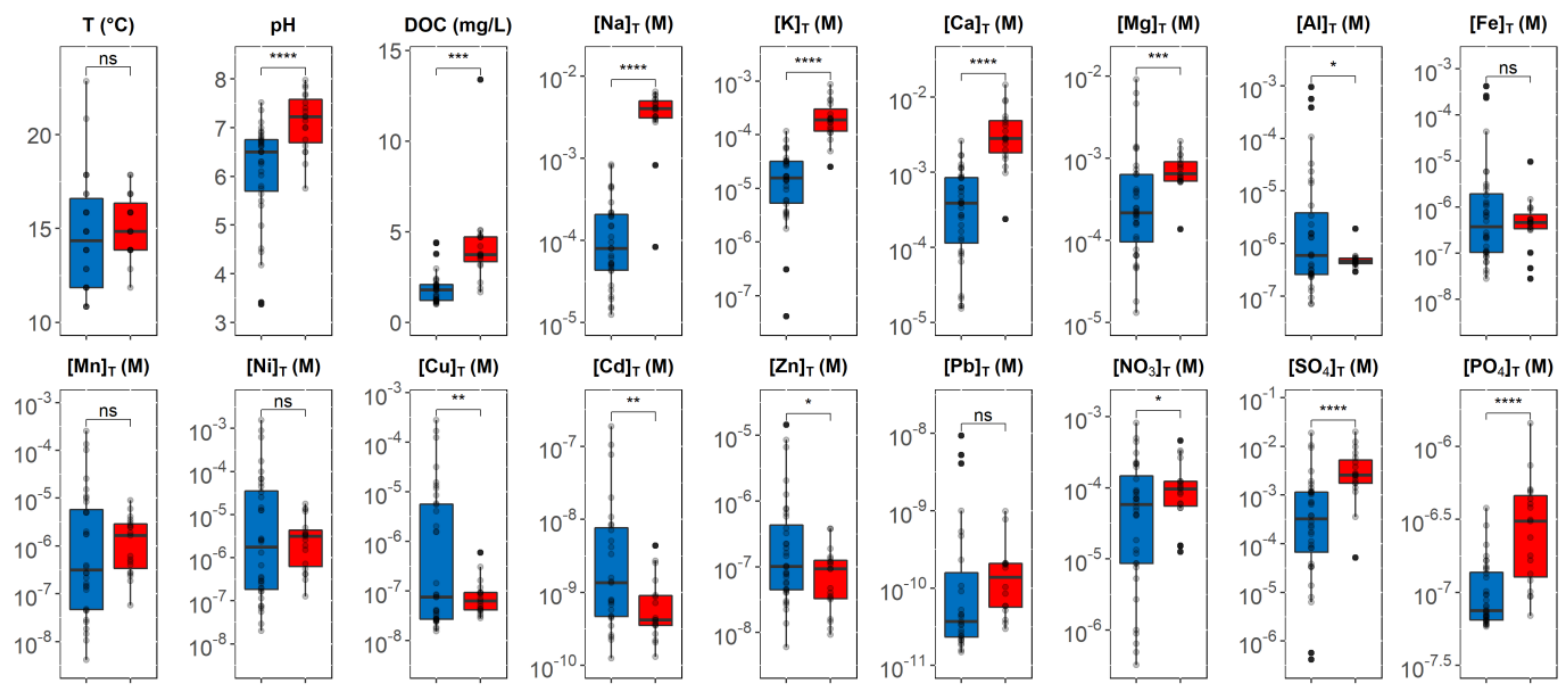

$[\mathrm{Pb}]_{\mathrm{T}}(\mathrm{M})$
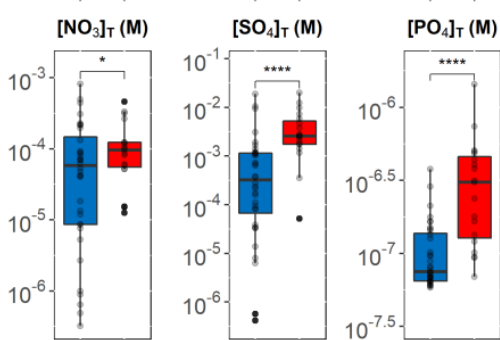

Figure 2: Box plots of major physicochemical parameters for the surface waters sampled in July and August for Nunavik (blue), and in September for Sudbury (red). Except for temperature and DOC, data are presented on a log scale. A t-test was performed on means for comparison with significance thresholds of: $p \leq 0.0001$ "****"; $p \leq 0.001$ “***"; $p \leq 0.01$ “**”; $p \leq 0.05$ “*”; $p>0.05$ "ns".
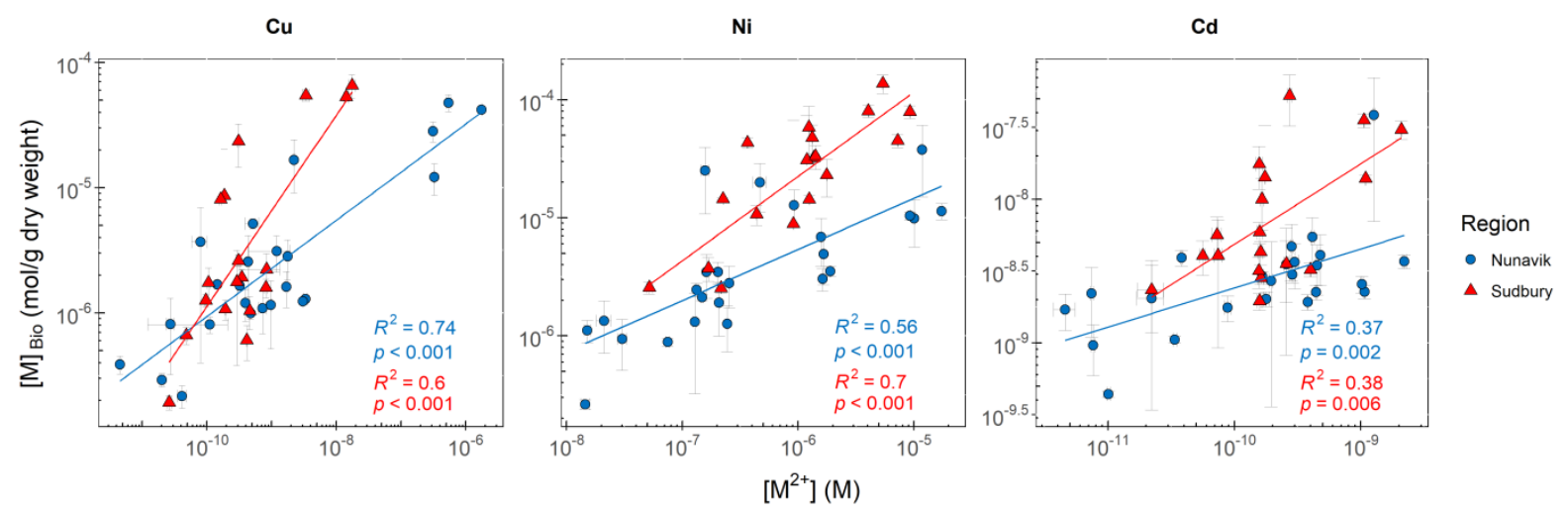

Figure 3: Regressions of biofilm metal contents ( $\mathrm{Cu}, \mathrm{Ni}$ and $\mathrm{Cd})$ as a function of free metal species $\left(\mathrm{Cu}^{2+}\right.$, $\mathrm{Ni}^{2+}, \mathrm{Cd}^{2+}$ ) for sites where $\mathrm{pH}>6$. Nunavik data are represented as blue circles and Sudbury data as red triangles. 

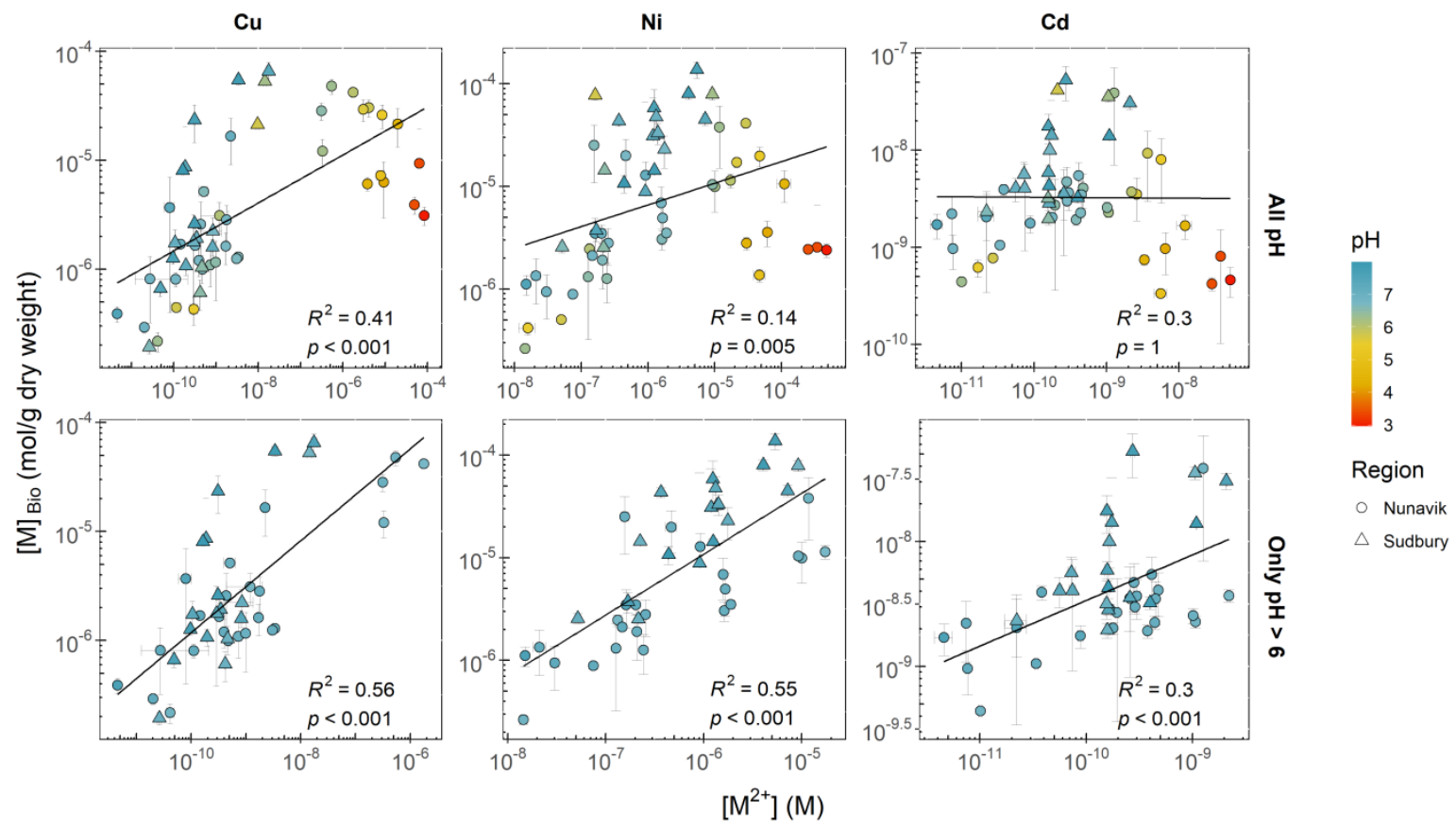

Figure 4: Linear regression analyses of biofilm metal contents ( $\mathrm{Cu}, \mathrm{Ni}$ and $\mathrm{Cd}$ ) as a function of free metal species $\left(\mathrm{Cu}^{2+}, \mathrm{Ni}^{2+}, \mathrm{Cd}^{2+}\right)$ for all samples from Nunavik (circles) and Sudbury (triangles) in 2016. The color gradient represents the observed $\mathrm{pH}$ values for each site. Upper figures represent data for biofilms collected at all sites and lower figures correspond to biofilms collected at sites with a pH higher than 6 . 


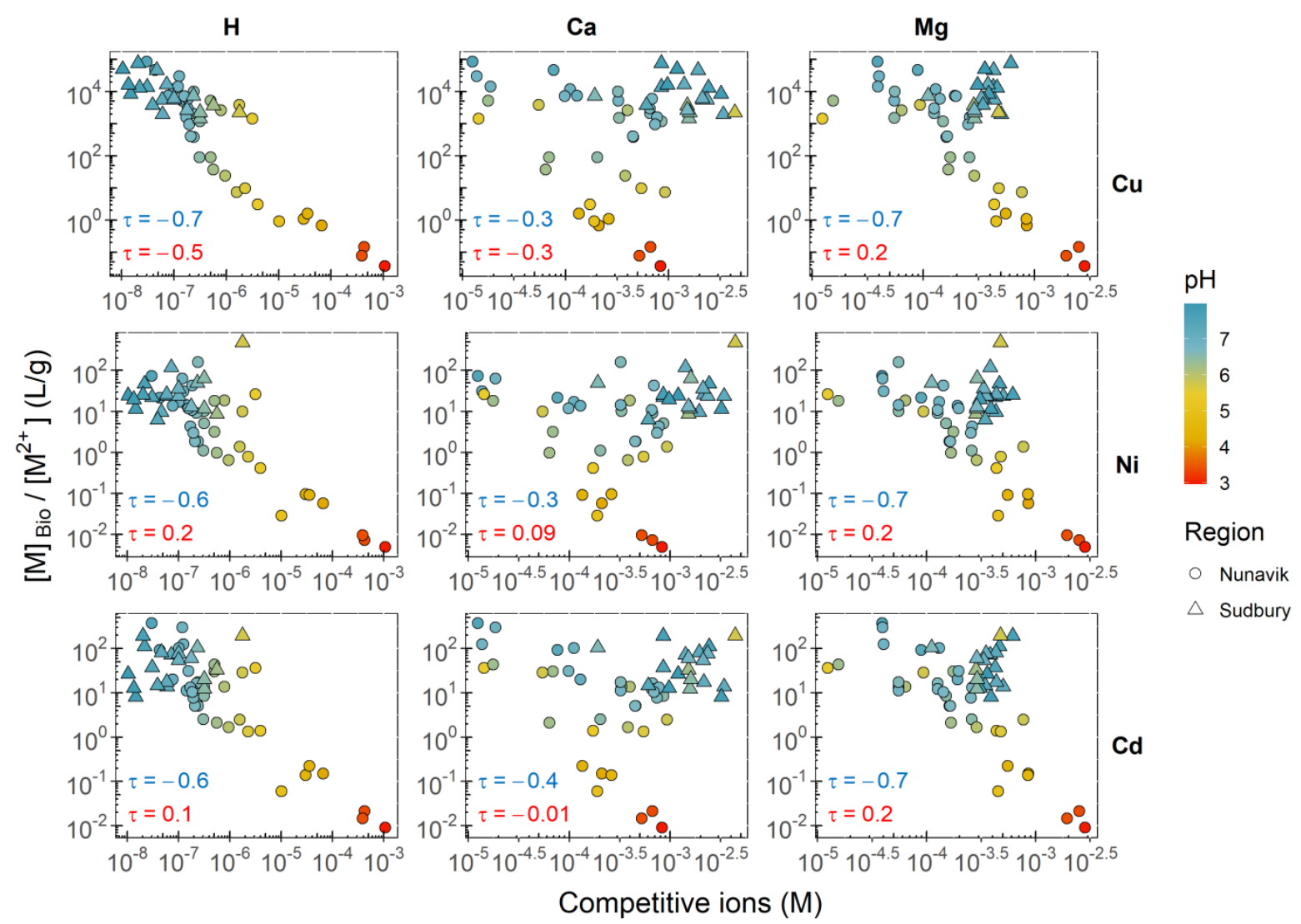

Figure 5: Ratio of biofilm metal contents to free metal ion concentrations for $\mathrm{Cu}, \mathrm{Ni}$ and $\mathrm{Cd}$ as a function of free proton, calcium, and magnesium concentrations. Symbols are identical to those used in Figures 3 and 4. Kendall's coefficients $(\tau)$ are presented for each region (blue for Nunavik and red for Sudbury). 

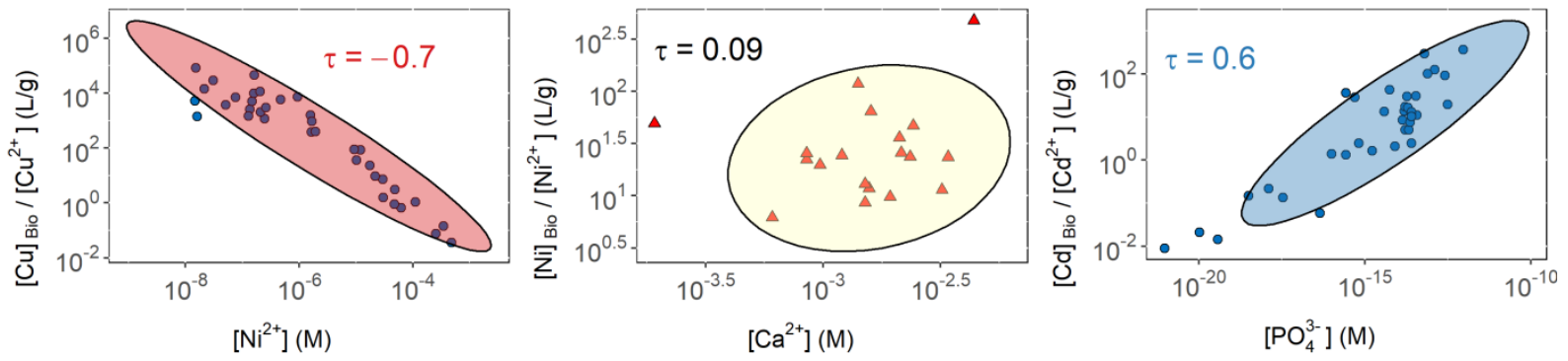

Nunavik

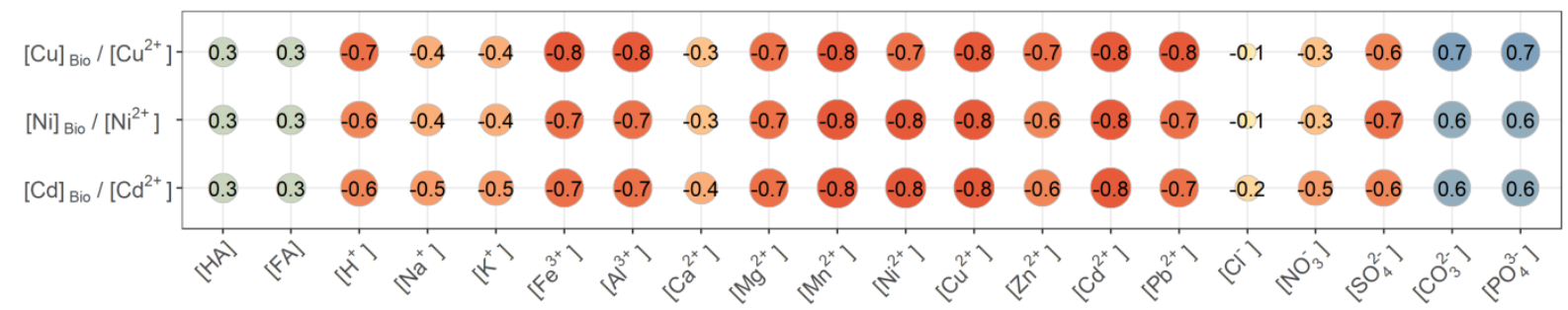

Sudbury

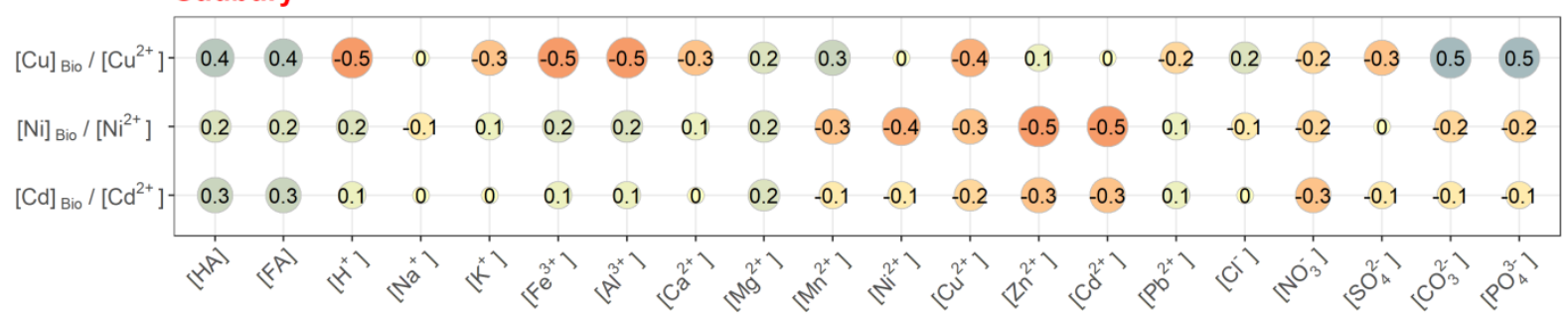

Figure 6: The upper panel presents three examples of correlations, with a lower Kendall coefficient indicating a greater effect of competition upon biofilm metal content (circles for Nunavik data and triangles for Sudbury data). The middle and lower panel presents, for each region, the ratio of biofilm metal content to free metal ion concentration for $\mathrm{Cu}, \mathrm{Ni}$ and $\mathrm{Cd}$ as a function of the free species. The values represent the Kendall's correlation coefficients. 